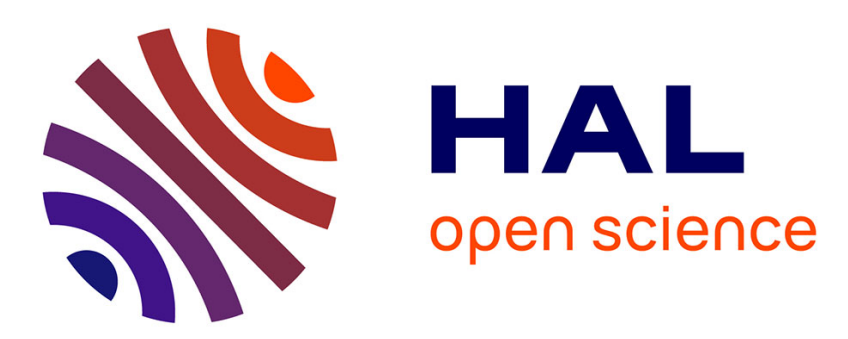

\title{
Solubility of inorganic salts in sub- and supercritical hydrothermal environment: Application to SCWO processes
}

Thomas Voisin, Arnaud Erriguible, David Ballenghien, David Mateos, André Kunegel, François Cansell, Cyril Aymonier

\section{To cite this version:}

Thomas Voisin, Arnaud Erriguible, David Ballenghien, David Mateos, André Kunegel, et al.. Solubility of inorganic salts in sub- and supercritical hydrothermal environment: Application to SCWO processes. Journal of Supercritical Fluids, 2017, 120, Part 1, pp.18-31. 10.1016/j.supflu.2016.09.020 . hal-01417006

\section{HAL Id: hal-01417006 \\ https://hal.science/hal-01417006}

Submitted on 2 Mar 2017

HAL is a multi-disciplinary open access archive for the deposit and dissemination of scientific research documents, whether they are published or not. The documents may come from teaching and research institutions in France or abroad, or from public or private research centers.
L'archive ouverte pluridisciplinaire HAL, est destinée au dépôt et à la diffusion de documents scientifiques de niveau recherche, publiés ou non, émanant des établissements d'enseignement et de recherche français ou étrangers, des laboratoires publics ou privés. 


\title{
Solubility of inorganic salts in sub- and supercritical hydrothermal environment: application for SCWO and SCWG processes
}

\author{
T. VOISIN ${ }^{a, b, c, d, *}$, A. ERRIGUIBLE ${ }^{a, c, *}$, D. BALLENGHIEN ${ }^{d}$, D.

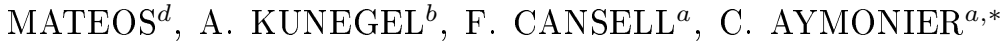 \\ ${ }^{a}$ CNRS, Univ. Bordeaux, ICMCB, UPR 9048, F-33600, Pessac, France. \\ ${ }^{b}$ French Environment and Energy Management Agency, \\ 20 avenue du Grésillé-BP 90406, 49004 Angers Cedex 01, France. \\ ${ }^{c}$ Université de Bordeaux, Bordeaux INP, CNRS, I2M-UMR5295, \\ site ENSCBP, 16 avenue Pey-Berland, Pessac Cedex, France. \\ ${ }^{d}$ INNOVEOX, 14 avenue Neil Armstrong, 33700 Merignac, France.*
}

\begin{abstract}
The supercritical water oxidation process (SCWO) is of great interest today in recycling toxic and/or complexed chemical wastes with very good efficiency. When reaching the critical conditions $\left(374^{\circ} \mathrm{C}, 22.1 \mathrm{MPa}\right)$, polarity collapses and water becomes a very good solvent for organic compounds. However, these interesting properties for organics turn to be problematic regarding dissolved inorganics. Commonly present in the aqueous waste, those inorganics precipitate easily when approaching the critical domain, leading to plugs in the process. In order to better understand the precipitation of salts in supercritical water, their solubility behaviour is of main interest. However, lots of relevant data are still missing in the literature. The aim of this review is to summarise most of the existing data regarding salt solubility in sub- and supercritical water as well as the different set up and methods developed over the past 50 years, including predictive theoretical modeling.
\end{abstract}

\section{Introduction}

Liquid water, as we know it in the normal conditions of temperature and pressure, is a strong polar solvent. This property designates water as a very good solvent for inorganic salts such as alkali and metallic salts or complexes, and a very bad one for organic compounds (oils, petroleum derivatives, polymers...). But in particular conditions of high temperature and pressure $\left(374^{\circ} \mathrm{C}\right.$, $22.1 \mathrm{MPa}$ ), water becomes supercritical, meaning a single phase is formed between liquid and vapor (c.f. Figure 1), resulting in intermediate properties (c.f. Figure 2). One of these particularities is that the water polarity collapses, leading to an overturn of the solubility abilities. More precisely, the polarity of a compound is mainly quantified with its dielectric constant $\varepsilon$ which decreases quickly with the temperature. This leads to the supercritical water polarity to be as low as non-polar solvents (like hexane...) so that water can now easily dissolve organic compounds, but with the drawback of inorganic precipitation.

This is the foreground for the Supercritical Water Oxidation process $(\mathrm{SCWO})$. Once the organic components of the waste have been dissolved, liquid oxygen is introduced in order to oxidize most of the compounds into basic inert molecules. The drawback of this phenomenon is that most of the inorganic compounds become nonsoluble in the media, leading to a massive precipitation into solids which can induce plug formation inside the

\footnotetext{
*cyril.aymonier@icmcb.cnrs.fr
}

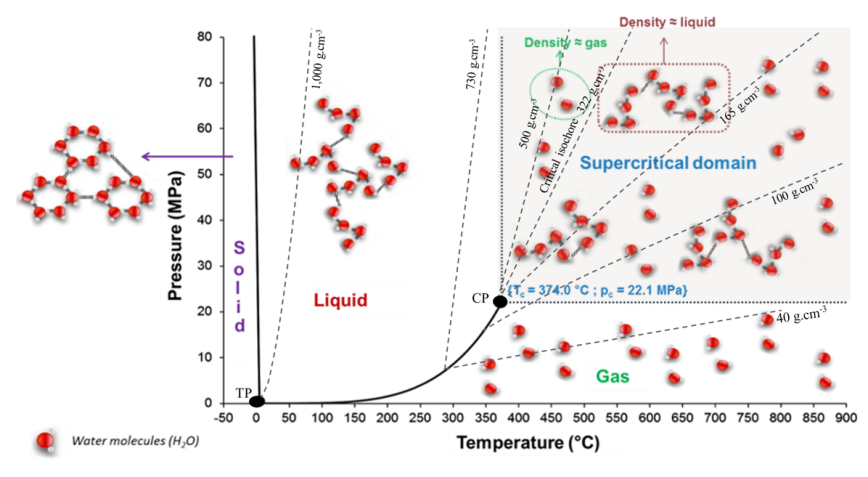

Figure 1: Pressure-temperature phase diagram of pure water (adapted from [1])

tubular reactors. Despite the fact that SCWO processes have been studied over the past 30 years, salt precipitation and plugging is paradoxically commonly known but the phenomenon is not well characterized. Besides, studies on salt precipitation and solubility in supercritical water are way scarcer.

The aim of this review is to sum up the experimental methods that have been developed in order to measure salt solubility in sub- and supercritical water as well as the theoretical modelling proposed for predictive calculation. After a short presentation of the SCWO processes and technologies, the notion of salt types will be introduced in a second part regarding water-salt equilibria. Consecutively, the third part concerns experimental setups for salt solubility measurement, with a historical review of the research in the field and a summary of all the solubility data available in sub- and supercritical water. 
Then, a part concerning salt mixtures and the influence on solubility will follow. And the last part will present the different theoretical and semi-empirical models for predictive calculation of inorganic salt solubility in suband supercritical conditions.

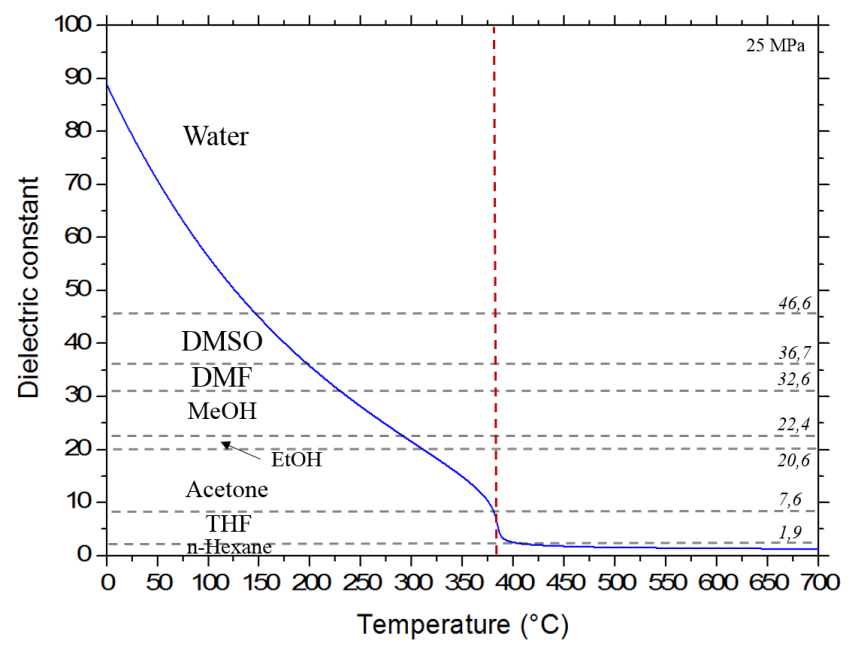

Figure 2: Changes in the dielectric constant of water according to the temperature, at $25 \mathrm{MPa}$. Comparison

with common solvent values at room pressure and temperature [2].

\section{Part I}

\section{Supercritical water oxidation process (SCWO)}

The main interest of the SCWO process is to treat a certain type of waste. Chemical liquid wastes are most of the time characterized by their Chemical Oxygen Demand (COD), expressing the amount of organic matter in the liquid phase. High organic rate (> 600 g.L-1) like some of the petroleum derivatives are often sent for incineration whereas low organic rate $(<25$ g.L-1) are reserved for biological oxidation in sewage treatment plants. This leaves an open window for the hydrothermal oxidative processes like SCWO.

The principle of the process is to take advantage of the properties of supercritical water, which is both a good solvent of organic molecules. In order to assure a complete oxidation, liquid oxygen, air, or hydrogen peroxide is also injected in the process. The working conditions are usually a pressure of $25 \mathrm{MPa}$ and temperatures from $300^{\circ} \mathrm{C}$ to up to $600^{\circ} \mathrm{C}$.

One of the advantages of the SCWO process is that it does not produce fumes or ashes, but mainly pure gases
$\left(\mathrm{CO}_{2}, \mathrm{~N}_{2}\right)$ and liquids $\left(\mathrm{H}_{2} \mathrm{O}\right.$, acids/basis $)$, depending on the composition of the waste. Furthermore the amount of NOx produced is negligible. As oxidation reactions are exothermic, it enables an autothermal process (meaning the heat released from oxidation is enough for keeping the process at the right temperature). For quite high COD (> 100 g.L-1) energy can be gained during the operation. Another main interest comes from the fact that SCWO process can easily reach $99.99 \%$ of waste degradation efficiency in very low residence time (few minutes) [3-5]. Figure 3 (a) shows the main products obtained with a SCWO process, depending on the composition of the waste.

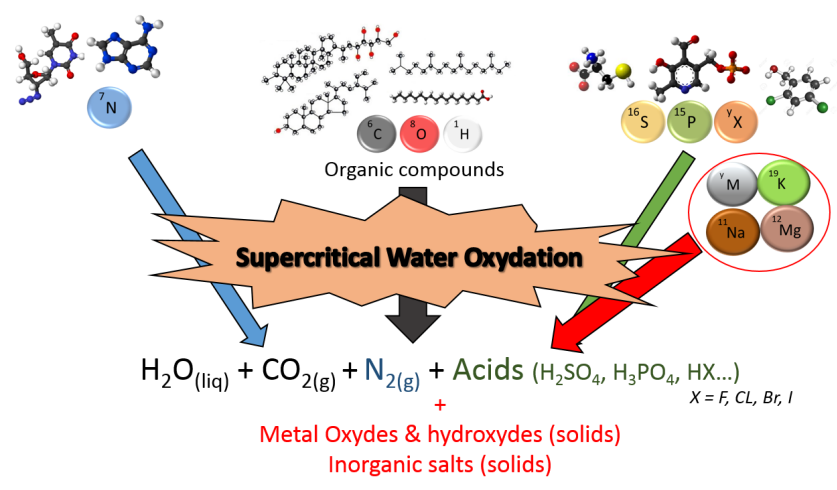

(a)

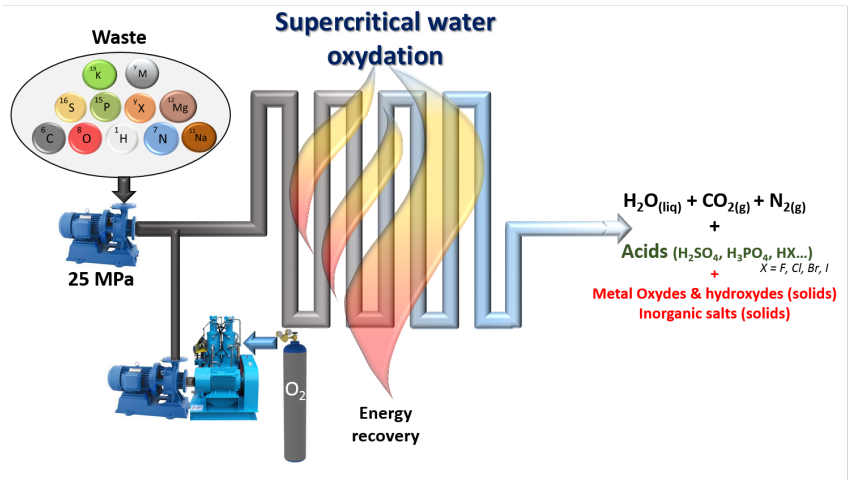

(b)

Figure 3: (a) Scheme of the main products obtained with SCWO processes. (b) General scheme of a SCWO process

A first limitation of SCWO processes is to deal with the corrosion resulting from the combination of high pressure and high temperature water, an oxidizing agent and corrosive species such as ions, heteroatoms or acids. This issue imposes SCWO plants to operate with corrosion resistant alloys such as super-alloys (Hastelloy-C, Inconel $625, \ldots)$ [6-8]. Another method consists in using a protective oxidation layer (such as titanium oxide) as a liner inside a stainless steel reactor.

As shown on Figure 3 (a), the second main limitation for SCWO plants comes from inorganic materials 
(metals or salts) which precipitate into solids and can remain stuck in the process, leading to plugs in the reactor. Over the past 30 years, research has been focused on the design of reactors, with the aim of solving the plugging problem[9-12]. Examples of designs are presented in Figure 4.

A large number of papers has been published about SCWO processes, dealing with reactor designs, scale control or waste treatment efficiency. A 2001 study [9] sums up most of the existing technologies for SCWO, but also the different remaining issues regarding corrosion, plugging and efficiency. A few years later, two reviews [13, 14] focused on the salt precipitation phenomenon in SCWO. Salt precipitation is a recurring subject in SCWO processes and lots of works have been done on the engineering of systems and reactors to try to counteract this drawback. One example is the MODAR reactor (c.f. Figure 4 (c)), also called reverse flow reactor, and is described by several works $[10,15,16]$ and patents $[17,18]$. Reverse flow reactor principle is to work with a supercritical zone (upper area of the reactor) where oxidation and waste degradation occurs, and a subcritical zone (lower area) where solid salt can be re-dissolved and be taken out as a concentrated brine. Some other SCWO reactors have been designed in order to reduce the corrosion and precipitation issues by keeping the reactor's wall cooler than the supercritical zone with an injection of compressed air or cold water (c.f. Figure $4(a))$. Examples are the wallcooled hydrothermal burner [19], the transpiring-wall reactors [20-22] or the cold wall reactor [23]. One company who is currently running a SCWO process at industrial scale is INNOVEOX in Europe, and is using a multiinjection tubular reactor, consisting in injecting pressurized oxygen at different stages of the process (c.f. Figure $4(b))$.

At a smaller scale, some other prototypes have been imagined for SCWO applications. One has been developed, using centrifugal forces to split the two phases based on the differences in weight and density between solid salts and supercritical water. Usually called vortex or cyclone reactors, several variety of reactors have been developed following this process, such as the centrifuge reactor [24], the hydrocyclone [25] or rotational spin reactor [26]. Another interesting design is the sonochemical reactor [27] (c.f. Figure $4(d)$ ), combining an ultrasound probe to activate oxidation reactions at lower temperatures to reduce the precipitation and corrosion issues.

Regarding the oxidative process efficiency, the reviews written by BRUNNER [5, 28, 29] , in 2009 are focused either on the destruction of organic biomass (lignin, cellulose...) or on the corrosion, depending on the solvent used, and the different available materials meeting the requirements to prevent it. One year later, a more specific work was done [30-32] on the salt precipitation problem, analysing different salt behaviors, with binary mixtures as well but few solubility measurements. A recent work on the salt issue [12] is focused on the deposition of sticky salts $\left(\mathrm{Na}_{2} \mathrm{CO}_{3}, \mathrm{Na}_{2} \mathrm{SO}_{4} \ldots\right)$ and the means to avoid it.

With respect to the commercially full scale process, a recent review [11] proposes an overview of most of the existing SCWO plants, with the description of the type of waste treated, the capacity and the type of reactors used. This work links up with a previous thesis done on the subject [3] in 2000. In this thesis, many different chemical wastes and compounds have been treated and analyzed in regard to the oxidative efficiency as well as a sum up of the different type of process, reactors and materials was done.

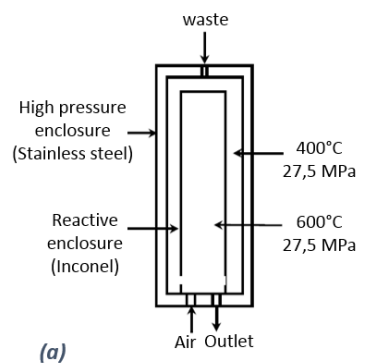

Double-wall reactor

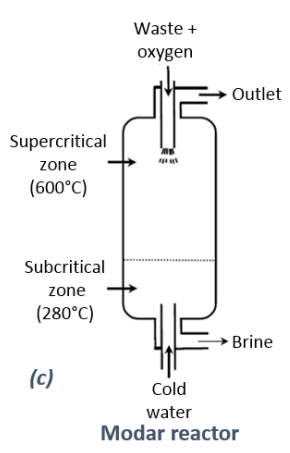

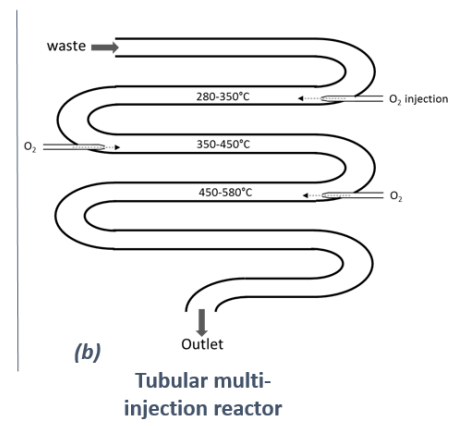

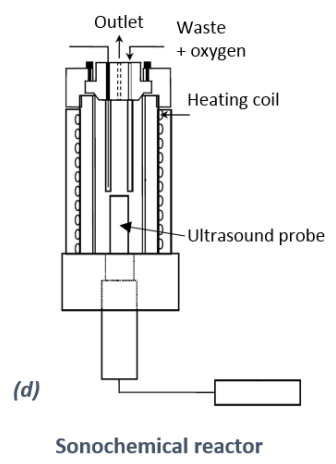

injection reactor

Figure 4: Some of the reactors specifically designed for SCWO in order to avoid plugs with precipitation (adapted from [3]).

SCWO process exhibits very interesting properties and benefits, in terms of efficiency, energy consumption or residence time. But some key issues remain a limiting factor for its industrial development, such as corrosion and/or salt precipitation. Despite the great investment put into the reactor designs research 30 years ago, no definitive solution has been found. However, research on salt behavior under sub- and supercritical water conditions has experienced a second wind with the recent interest in using supercritical water for biomass conversion, and material recycling [33-35]. 
Part II

\section{Water-salts equilibria and types of salts}

As introduced, the general trend for inorganic salts is to precipitate when reaching supercritical conditions for water. However, phase behavior with water varies a lot depending on the nature of the salt. Lots of works have been done to try to classify salts regarding to their behavior in supercritical water. First, SCOTT \& VAN KONYNENBURG [36] classified 6 types of binary fluid phase diagrams, using the Van Der Waals equation of state. Differences between the diagrams are characterized by the immiscibility or miscibility domains and the configuration of the critical lines between the two critical points of the pure compounds. A seventh type has then been discovered [37] with the Lennard-Jones equation of state. Following this work, VALYASHKO [38-40] used some of these diagrams which enable the description of solid-fluid interactions, such as salt-water systems. However, due to the large difference in critical temperature between inorganic salts and water (in comparison with two fluids for example), unusual phase equilibrium can occur when reaching the critical domain. In order to better build these diagrams, some specific assumptions to the water-salt systems have been added (taken from [38]):

1. The melting temperature of the pure nonvolatile component (salt) is higher than the critical temperature of the volatile component

2. No solid-phase transition (polymorphism, solidsolution...) or azeotropy in liquid-gas equilibria is considered

3. Liquid immiscibility is terminated by the critical region at high pressures and cannot be represented by more than two separated immiscibility regions of different types

4. All geometric elements of phase diagrams, their reactions and shapes (but not the combinations of these elements) can be illustrated by existing experimental examples.

Using a continuous topological transformation approach, the results reveal two main behaviors for salts (type I and type II), which are split into many sub-diagrams. Operating small changes on thermodynamical parameters allow to process a continuous transformation from one diagram to another[38, 41].

These thermodynamic binary phase diagrams nicely classify most of the salts according to their behavior in supercritical water. Following this classification, type I salts present a continuous solubility curve at supercritical temperature which does not cross the critical curve, whereas type II salts present an intersection between the solubility curve and the critical curve, leading to two critical endpoints in this domain (c.f. Figure 5).

These two general diagrams can then be complicated with immiscibility domains occurring in some cases. MARSHALL [42] made a difference between type I and type II salts saying that the first group generally has a higher solubility in supercritical water than the others, and classified most of inorganic salts according to this criteria (c.f table I). In addition, VALYASHKO [43] classified them according to their melting temperatures (c.f. table I). Type I salts have a melting temperature between $800^{\circ} \mathrm{C}$ and $1000^{\circ} \mathrm{C}$ whereas type II salts have their melting temperature above $700-800^{\circ} \mathrm{C}$. What is interesting is that the two classifications are not in opposition with each other, but complementary. It is also important to notice that according to this classification, for a given cation (anion), the salts solubility in supercritical water will increase with the size of the associated anion (cation).

\begin{tabular}{|c|c|}
\hline Type I salts & Type II salts \\
\hline \multicolumn{2}{|c|}{ According to Marshall classification } \\
\hline $\begin{array}{l}\mathrm{LiClO}_{4} \\
\mathrm{NaCl}, \mathrm{NaBr}, \mathrm{Nal}, \mathrm{NaNO}_{3}, \mathrm{Na}_{2} \mathrm{SeO}_{4} \\
\mathrm{KCl}, \mathrm{KBr}, \mathrm{Kl}, \mathrm{KNO}_{3}, \mathrm{KBrO}_{3}, \mathrm{KIO}_{3}, \mathrm{~K}_{2} \mathrm{CrO}_{4}, \mathrm{KReO}_{4} \\
\mathrm{NH}_{4} \mathrm{Cl}, \mathrm{NH}_{4} \mathrm{Br}_{4},\left(\mathrm{NH}_{4}\right)_{2} \mathrm{SO}_{4} \\
\mathrm{MgCl}_{2}, \mathrm{MgI}_{2} \\
\mathrm{CaCl}_{2} \\
\mathrm{SrCl}_{2}, \mathrm{SrBr}_{2}, \mathrm{Sr}\left(\mathrm{NO}_{3}\right)_{2} \\
\mathrm{BaCl}_{2}, \mathrm{BaBr}_{2}, \mathrm{Ba}\left(\mathrm{NO}_{3}\right)_{2} \\
\mathrm{MnCl}_{2} \\
\mathrm{FeCl}_{3} \\
\mathrm{ZnCl}_{2} \\
\mathrm{CdCl}_{2}, \mathrm{CdBr}_{2}, \mathrm{Cdl}_{2}, \mathrm{Cd}\left(\mathrm{ClO}_{4}\right)_{2} \\
\mathrm{HgCl}_{2} \\
\mathrm{TiCl} \mathrm{Ti}_{2} \mathrm{SO}_{4} \\
\mathrm{PbCl}_{2}, \mathrm{PbBr}_{2}\end{array}$ & $\begin{array}{l}\mathrm{Li}_{2} \mathrm{SO}_{4} \\
\mathrm{Na}_{2} \mathrm{SO}_{4}, \mathrm{Na}_{2} \mathrm{CO}_{3} \\
\mathrm{Na}_{3} \mathrm{PO}_{4} \\
\mathrm{~K}_{2} \mathrm{SO}_{4}\end{array}$ \\
\hline \multicolumn{2}{|c|}{ According to Valyashko classification } \\
\hline $\begin{array}{l}\mathrm{KF}, \mathrm{RbF}, \mathrm{CsF} \\
\mathrm{LiCl}, \mathrm{LiBr}, \mathrm{Lil} \\
\mathrm{NaCl}, \mathrm{NaBr}, \mathrm{Nal} \\
\mathrm{K}_{2} \mathrm{CO}_{3}, \mathrm{Rb}_{2} \mathrm{CO}_{3} \\
\mathrm{Rb}_{2} \mathrm{SO}_{4} \\
\mathrm{Na}_{2} \mathrm{SeO}_{4} \\
\mathrm{~K}_{2} \mathrm{SiO}_{3} \\
\mathrm{~K}_{3} \mathrm{PO}_{4} \\
\mathrm{CaCl}_{2}, \mathrm{CaBr}_{2}, \mathrm{Cal}_{2} \\
\mathrm{SrCl}_{2}, \mathrm{SrBr}_{2} \\
\mathrm{BaCl}_{2}, \mathrm{BaBr}_{2}\end{array}$ & $\begin{array}{l}\mathrm{LiF}, \mathrm{NaF} \\
\mathrm{LiF} \\
\mathrm{NaF} \\
\mathrm{Li}_{2} \mathrm{CO}_{3}, \mathrm{Na}_{2} \mathrm{CO}_{3} \\
\mathrm{Li}_{2} \mathrm{SO}_{4}, \mathrm{Na}_{2} \mathrm{SO}_{4}, \mathrm{~K}_{2} \mathrm{SO}_{4}, \mathrm{KLiSO}_{4} \\
\mathrm{Li}_{2} \mathrm{SiO}_{3}, \mathrm{Na}_{2} \mathrm{SiO}_{3} \\
\mathrm{Li}_{3} \mathrm{PO}_{4}, \mathrm{Na}_{3} \mathrm{PO}_{4} \\
\mathrm{CaF}_{2} \\
\mathrm{SrF}_{2} \\
\mathrm{BaF}_{2}\end{array}$ \\
\hline
\end{tabular}

Table I: MARSHALL and VALYASHKO classifications for type I and type II salts.

As appearing in the different classifications, sodium chloride $(\mathrm{NaCl})$ is a very good illustration of a type I salt, with a high solubility in water, even at sub-critical or supercritical conditions (compare to other salts), and the appearance of gas-liquid like equilibrium. The binary diagram at high pressure and high temperature for $\mathrm{NaCl}$ is well defined (c.f. Figure 6) and has been checked with several experimental data [44]. The lower limit of the diphasic zone has also been directly observed, but its upper limit remains theoritically fixed to a certain temperature from which a unique supercritical phase remains and salt precipitates.

A good example of a type II salt is sodium sulfate $\left(\mathrm{Na}_{2} \mathrm{SO}_{4}\right)$, which presents an intersection of the solubility curve with the critical curve, leading to a simple 


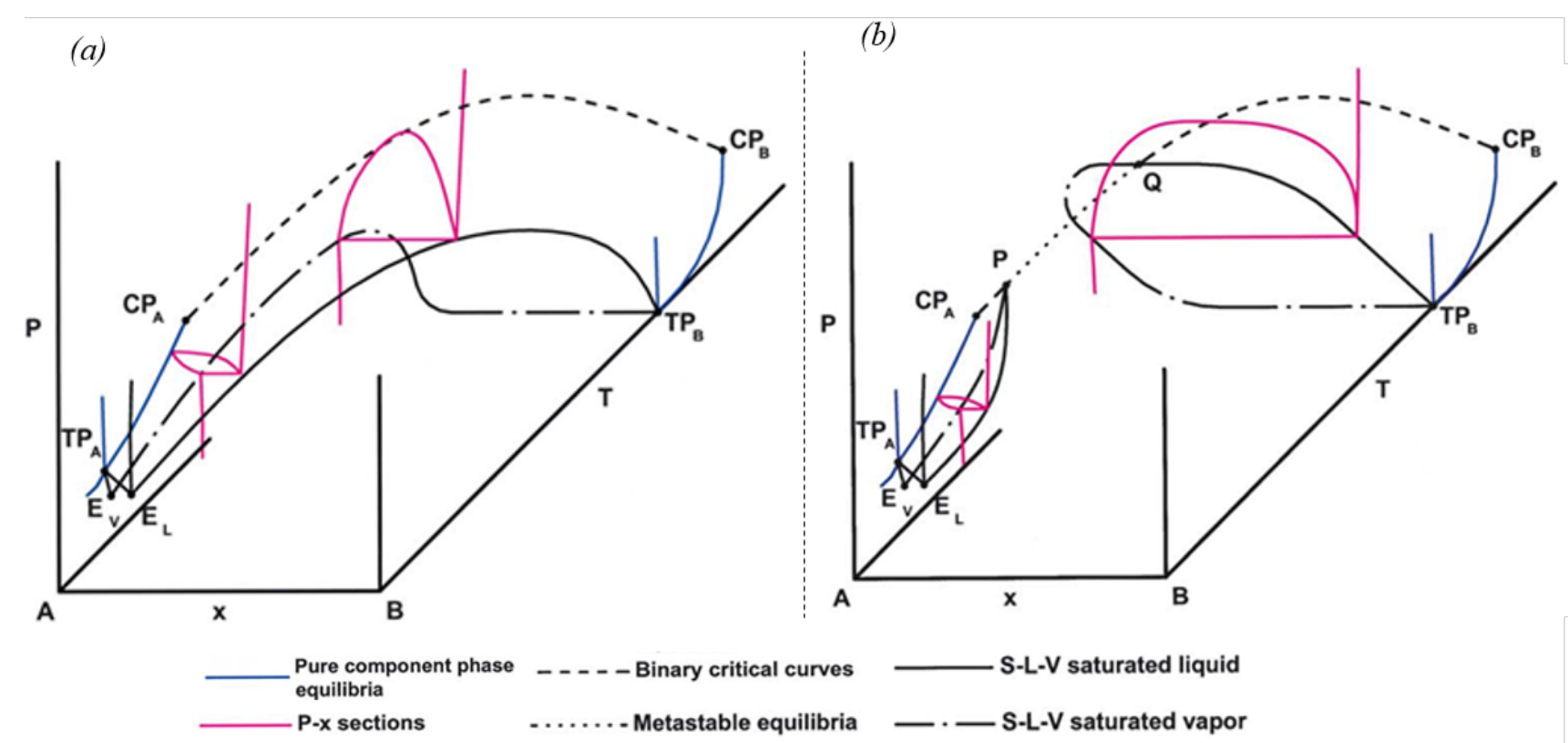

Figure 5: P-T-x diagrams for a type I salt (a) and a type II salt (b). For a type I salt, the binary critical curve is continuous and distinct from the saturation curves, whereas for the type II the binary critical curve is interrupted by the saturation curves, leading to critical end points P and Q. Abbreviations: A, volatile compound ; B, nonvolatile compound ; TP, triple point ; $\mathrm{CP}$, critical point ; $\mathrm{E}_{V}$, eutectic vapor coordinates ; $\mathrm{E}_{L}$, eutectic liquid coordinates ; $\mathrm{P}, \mathrm{A}-\mathrm{rich}$ S-L-V critical end point ; Q, B-rich S-L-V critical end point (from [13]).

precipitation behavior at subcritical conditions, without 3 -phase equilibrium (see Figure 6). Some recent experiments have been performed on the subject, towards improvement of gasification processes [30-32]. The set up is a Modar like reactor, with a subcritical part at the bottom and a supercritical zone on the top. The aim of this set up is to study the different salt behavior, depending on their type, by looking at their ability to be recovered from the bottom part of the reactor. Experiments were performed with binary mixtures of water-salt systems, with type I or type II salts. The first trend observed is that type I salts $\left(\mathrm{K}_{2} \mathrm{CO}_{3}, \mathrm{~K}_{3} \mathrm{PO}_{4}, \mathrm{~K}_{2} \mathrm{HPO}_{4}\right.$, $\mathrm{KH}_{2} \mathrm{PO}_{4}, \mathrm{NaNO}_{3}, \mathrm{KNO}_{3}$ and $\left.\mathrm{Ca}\left(\mathrm{NO}_{3}\right)_{2}\right)$ precipitate in supercritical water and can be recovered as a brine solution, whereas type II salts $\left(\mathrm{Na}_{2} \mathrm{CO}_{3}, \mathrm{Na}_{2} \mathrm{SO}_{4}, \mathrm{~K}_{2} \mathrm{SO}_{4}\right.$ and $\mathrm{Na}_{3} \mathrm{PO}_{4}$ ) precipitate but directly stick to the reactor walls and rapidly plug the process, disabling any recovery as a brine. But even if the behavior follows the same trend for a salt type, differences still exist due to the solubility variations. This is seen in the nitrate compounds, the solubility of $\mathrm{NaNO}_{3}$ is higher than the one of $\mathrm{KNO}_{3}$, itself higher than $\mathrm{Ca}\left(\mathrm{NO}_{3}\right)_{2}$ (meaning $\mathrm{Ca}\left(\mathrm{NO}_{3}\right)_{2}$ is easily recovered than $\mathrm{NaNO}_{3}$ because it precipitates more easily). As a similar result, $\mathrm{KH}_{2} \mathrm{PO}_{4}$ is easily recovered in comparison with $\mathrm{KNO}_{3}$. These results seem to be on the opposite trend than the one predicted by MARSHALL [42] and VALYASHKO [43] classifications (solubility increases, for a given anion, with the size of the cation and vice versa).

In the end, this classification in types of salt cannot give all the information regarding solubility at supercritical conditions but it can be used as a trend for the general behavior.
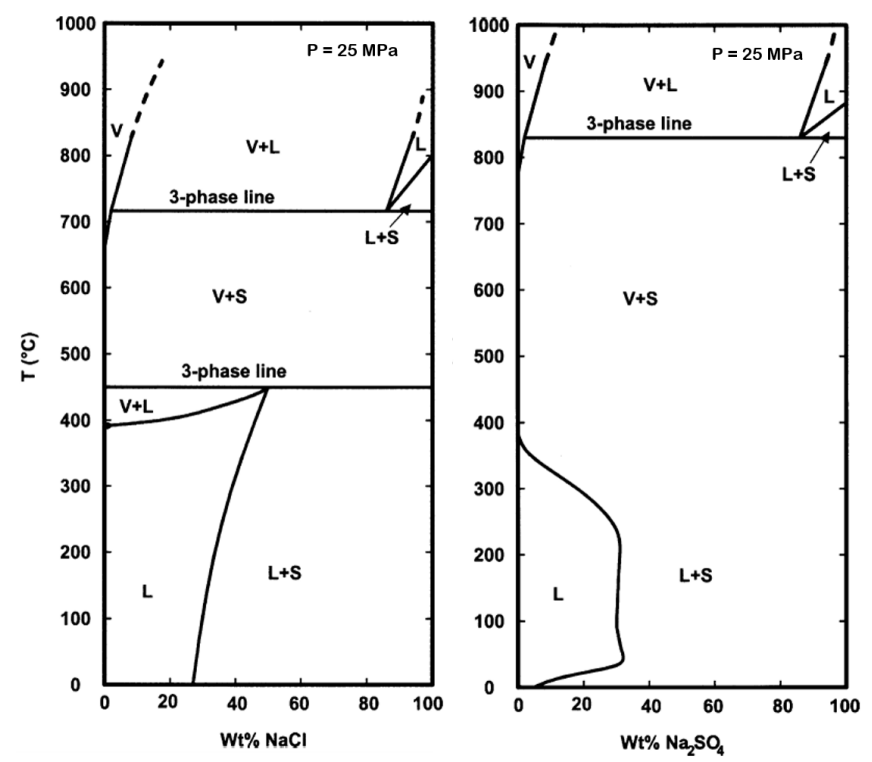

Figure 6: Binary diagrams at $25 \mathrm{MPa}$ for water- $\mathrm{NaCl}$ (left) and water- $\mathrm{Na}_{2} \mathrm{SO}_{4}$ (right). $\mathrm{L}=$ liquid phase; $\mathrm{V}=$ vapor phase; $\mathrm{S}=$ solid phase (from [13]) 


\section{Part III}

\section{Solubility measurements for inorganic salts in sub- and supercritical water}

Inorganic materials, like metallic or inorganic salts, are highly soluble in water for temperatures under $200^{\circ} \mathrm{C}$. This solubility is strongly dependent on the dielectric constant of water which is dropping down when reaching the supercritical domain. Thus, inorganics precipitate, leading to the well-known problem of reactor plugging. The initial studies for salt solubility at high temperatures and pressures were first done for geological purpose $[45,46]$ in the 40s. These first analyses were performed with vapor pressure measurements at different temperatures, up to $650^{\circ} \mathrm{C}$. Various salted solutions of potassium based salts [45] and sodium based salts [46] were investigated.

Then, several authors have investigated the phase equilibrium of the $\mathrm{NaCl}-\mathrm{H}_{2} \mathrm{O}$ system at high temperatures and pressures, including the supercritical domain, with vapor pressure measurement [51-55]. Following the keen interest in the phase equilibria for the binary system $\mathrm{NaCl}-\mathrm{H}_{2} \mathrm{O}$, a comparison of all the data of the previous studies was carried out [56], looking at the trends and disagreements between the results. Experiments were also performed to complete the lack of data near the critical temperature of water and re-determine some vaporliquid-halite phases where disagreement existed. In order to better understand the salt deposition (mainly sodium based salts) occurring in turbines and steam machines, which induces fatigue cracking, wearing and mechanical failures, the solubility of sodium chloride in steam at high temperature $\left(450-500^{\circ} \mathrm{C}\right)$ and pressure $(5-10 \mathrm{MPa})$ was mainly studied $[57,58]$. The water steam was analysed in a continuous process with a flame spectroscopy detector at the end, in order to detect the sodium concentration according to time. Among all the previous cited papers, it was the only one to provide details about experimental setup and procedure. Other continuous processes can be found in previous works [59-61] where solubility measurements were made using chloride titrations (colorimetric or volumetric analysis). Alternative methods for $\mathrm{NaCl}$ concentration measurements used the titration of $\mathrm{Na}^{+}$ ions by ion-chromatography, or even ${ }^{22} \mathrm{Na}$ radioactive tracers in batch system [62,63], where this method is used as an in situ analysis.

In addition to all researches on sodium chloride solutions in sub- or supercritical water, some experiments have also been performed on sodium sulfate solutions, in the same range of temperature, pressure, and with an equivalent geological purpose. Studies on $\mathrm{Na}_{2} \mathrm{SO}_{4}$ solubility in steam have also been performed [59, 64, 65]. Salt concentration measurements were mostly done us- ing a ${ }^{35} \mathrm{~S}$ radioactive tracer in continuous systems.

In 1993, the first paper about experimental results for the solubility of salts in sub- and supercritical water, towards the SCWO application, was published by ARMELLINI and TESTER [47] . This work summarizes most of the previous results on sodium chloride and sodium sulfate solubility in steam, comparing the measurement methods and editing the temperature and pressure domains screened by the past researches. A detailed description of the experimental setup and method is given, as well as a fitting of the data with a GibbsHelmholtz model which is compared with some other theoretical solubility models.

In opposition to the past experimental methods, which usually consisted of heating a brine solution and then analysing the salt concentration remaining inside, this new setup (c.f. Figure $7(a)$ ) proposes a different approach: a pure water solution is introduced, pressurized and heated up, then the water passes through a tube filled with salt crystals in order to dissolve them and saturate the water to the maximum concentration. Then the solution is analysed using ICP measurements. The interest in using such a method is that it prevents the pipes from plugging, but it can only be used with low saturation concentration value due to the limited amount of salt inside the pipe.

This kind of process has also been used by other authors $[48,66]$ for several inorganic salts. In opposition, some use the reverse process, consisting in heating a brine solution in order to precipitate the salts. Thus, the remaining solution is at the saturation concentration for the chosen conditions of pressure and temperature. This method is particularly useful when analysing salts with a low melting temperature, as with nitrate salts [49] (c.f. Figure 7 (c)). Following this, LEUSBROCK et al. [67] (2009-2010) used this alternative method for different salts, without limitation to the low melting temperature ones (c.f. Figure 7 (b)).

It is interesting to notice that one set up [50] combines the precipitation and the dissolution of the salts $\left(\mathrm{Na}_{2} \mathrm{SO}_{4}\right.$ and $\left.\mathrm{Na}_{2} \mathrm{CO}_{3}\right)$ to analyse the solubility in supercritical water (c.f. Figure $7(d)$ ). In fact, sodium sulfate and sodium carbonate salts are commonly considered as "sticky salts", which precipitate easily on reactor walls. Using a flow conductivity cell at the end of their setup, the salt concentration is known continually according to time. A brine solution is passed through the system, pressurized and heated up. The conductivity will decrease while the salt precipitate in the reactor; when the steady state is reached (conductivity drops to a plateau), pure water is passed through, dissolving the salt inside. At this point, the pure water is saturated to a concentration similar to the one of the exiting brine before, thus conductivity remains the same until there is not enough salt to saturate the water anymore. This method enables the comparison of solubility values between solubilisation and precipitation methods.

All the solubility data regarding inorganic salt in sub- 
(a)

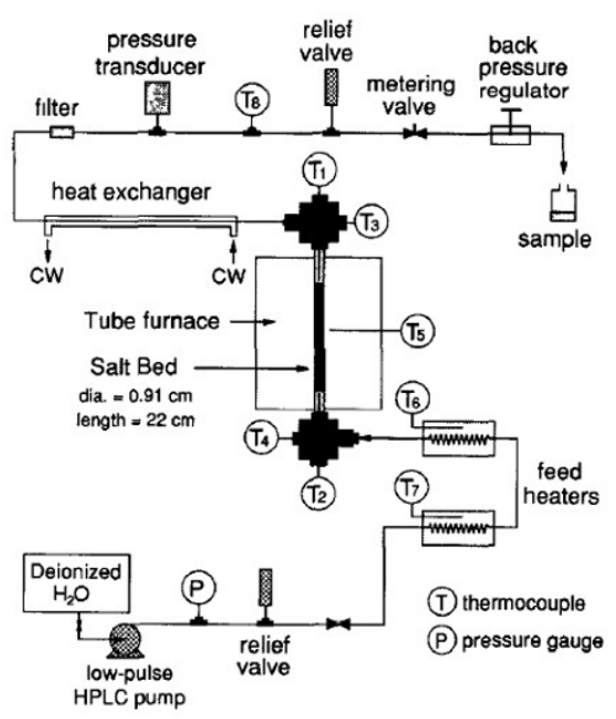

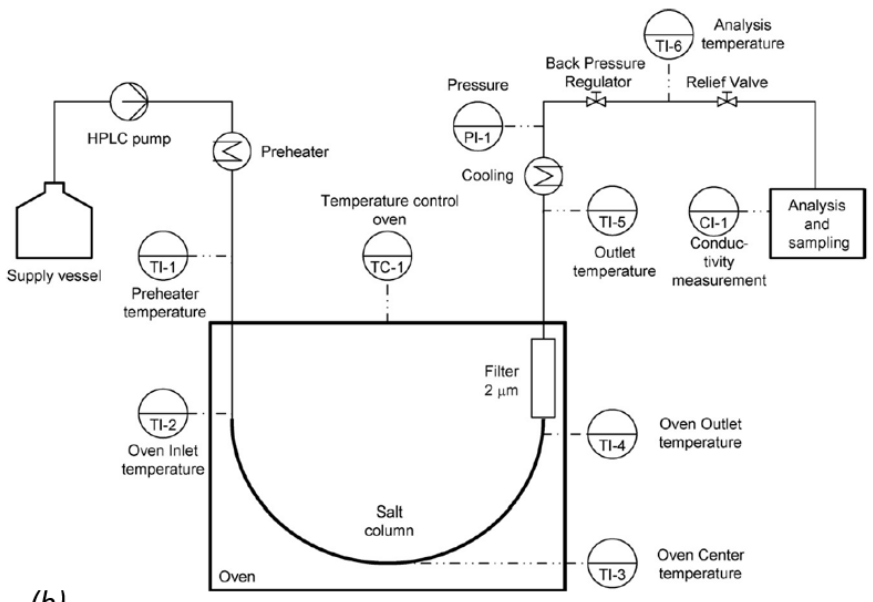

(b)

(c)
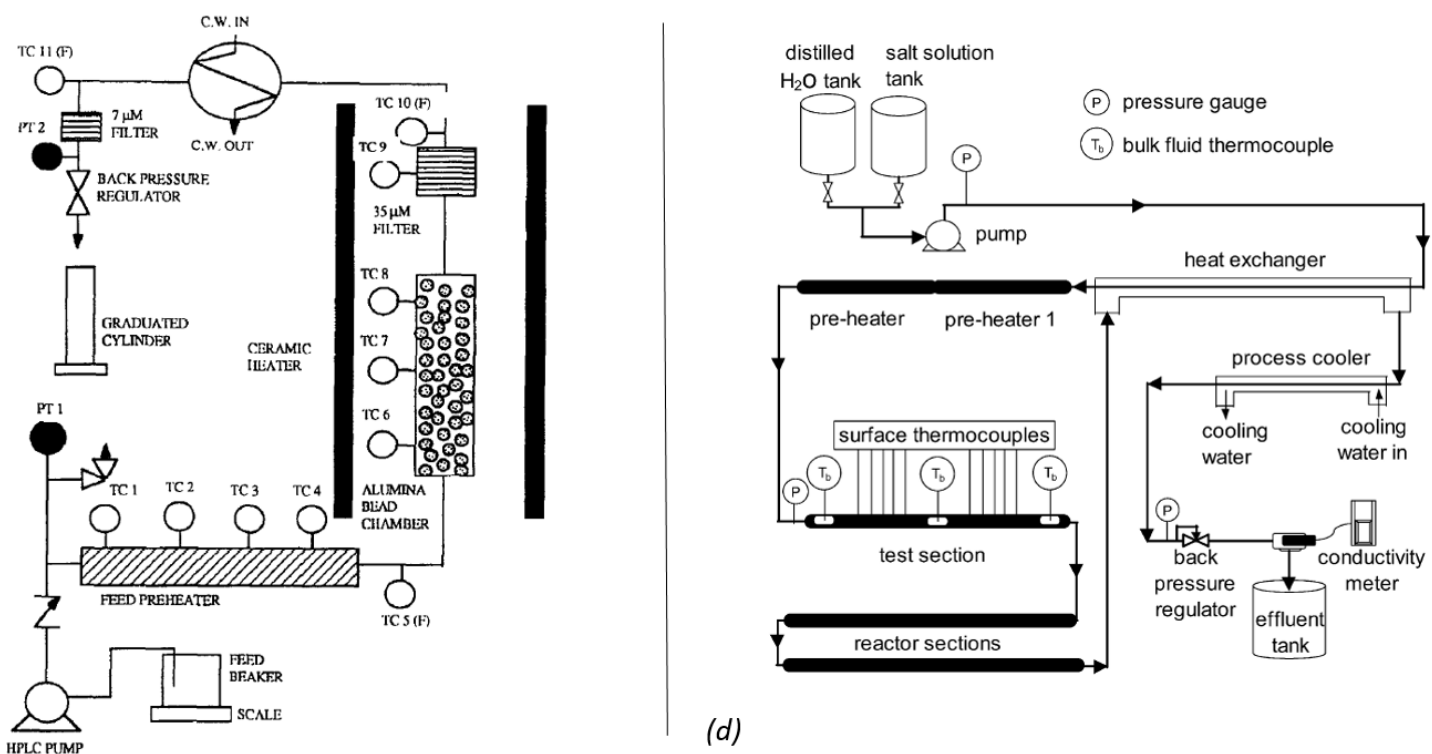

(d)

Figure 7: Schemes of different experimental set up for salt solubility measurement. (a) Set ups for the "salt bed" method used by ARMELLINI \& TESTER [47] ; (b) Structure for salt bed or precipitation method used by LEUSBROCK et al. [48]; (c) Precipitation apparatus used by Dell'ORCO et al. for low melting temperature salts [49]; (d) SCWO plant for salt deposition \& salt bed method used by KHAN \& ROGAK[50].

and supercritical water are represented in the right column of Figure 8. From one data set to another, pressure may vary. In order to have a global representation of the data, solubility values (in ppm) have been represented according to the water density, which takes into account pressure and temperature variations, and is often the key parameter for salt solubility. It appears from these graphics that chloride salts $(\mathrm{NaCl}, \mathrm{KCl}, \ldots)$ have very close solubility values when changing the alkali cation, but alkaline earth compound seems to have a slightly lower solubility. Similarly, nitrate salts have very close solubility values, independently of the counter cation. Comparatively, sulfate salts appear to have lower solubility values and phosphates seem to have large solubility dependency according to their hydration level and counter cation. Few data are available regarding other types of salts.

Many other methods can be used to measure the solubility of salts. When studying molecular ions $\left(\mathrm{SO}_{4}^{2-}\right.$, $\left.\mathrm{CO}_{3}^{2-} \ldots\right)$, spectroscopy can be used as an in situ analysis to follow the ion concentration. This kind of method includes the use of sapphire windows in order to point the analysing light through the media. This kind of set up is used to detect into which type of phase the inor- 

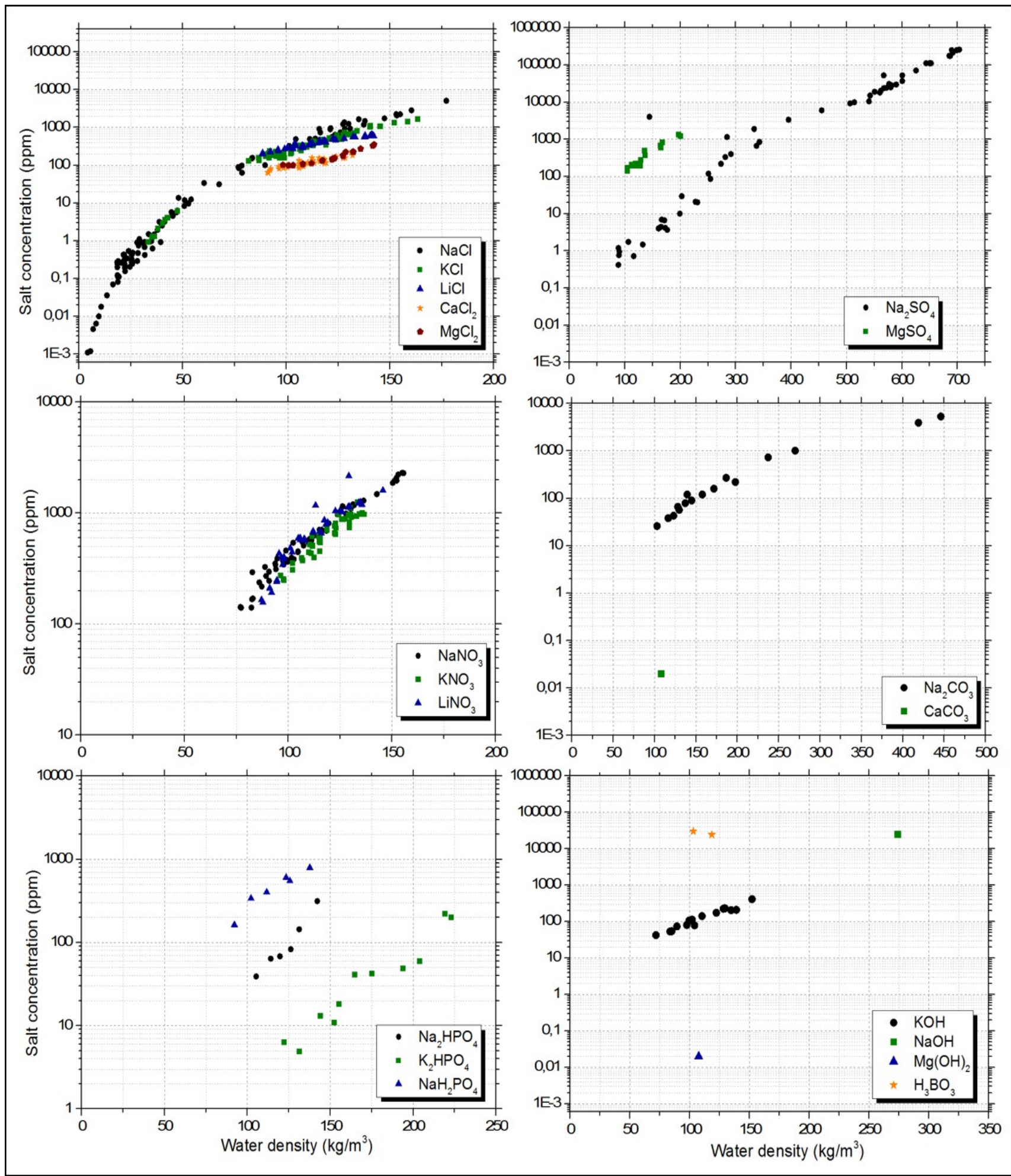

Figure 8: Presentation of all the solubility data available in the literature for inorganic salt in sub- and supercritical water as a function of the water density. 


\begin{tabular}{|c|c|c|c|c|}
\hline Salt & Authors \& year & Temperature $\left({ }^{\circ} \mathrm{C}\right)$ & Pressure (MPa) & Reference \\
\hline \multirow{2}{*}{$\mathrm{KCl}$} & \multirow{2}{*}{$\begin{array}{l}\text { HIGASHI et al. }(2005) \\
\text { LEUSBROCK et al. }(2009)\end{array}$} & \multirow{2}{*}{$\begin{array}{l}370-400 \\
395-405\end{array}$} & \multirow{2}{*}{$\begin{array}{c}9-12 \\
18-24\end{array}$} & {$[66]$} \\
\hline & & & & [67] \\
\hline $\mathrm{LiCl}$ & LEUSBROCK et al. (2009) & $388-419$ & $19-24$ & [67] \\
\hline \multirow{2}{*}{$\mathrm{NaNO}_{3}$} & \multirow{2}{*}{$\begin{array}{c}\text { P. Dell'ORCO (1995) } \\
\text { LEUSBROCK et al. (2009) }\end{array}$} & \multirow{2}{*}{$\begin{array}{l}450-525 \\
390-406\end{array}$} & \multirow{2}{*}{$\begin{array}{l}25-31 \\
17-23\end{array}$} & [49] \\
\hline & & & & {$[67]$} \\
\hline \multirow{2}{*}{$\mathrm{KNO}_{3}$} & \multirow{2}{*}{$\begin{array}{c}\text { P. Dell'ORCO (1995) } \\
\text { LEUSBROCK et al. (2009) }\end{array}$} & \multirow{2}{*}{$\begin{array}{c}475 \\
400-410\end{array}$} & \multirow{2}{*}{$\begin{array}{l}25-30 \\
20-24\end{array}$} & [49] \\
\hline & & & & [67] \\
\hline \multirow{2}{*}{$\mathrm{LiNO}_{3}$} & \multirow{2}{*}{$\begin{array}{c}\text { P. Dell'ORCO (1995) } \\
\text { LEUSBROCK et al. (2009) }\end{array}$} & \multirow{2}{*}{$\begin{array}{c}475 \\
390-405\end{array}$} & \multirow{2}{*}{$\begin{array}{l}25-30 \\
18-24\end{array}$} & [49] \\
\hline & & & & [67] \\
\hline $\mathrm{CaCl}_{2}$ & LEUSBROCK et al. (2010) & $395-415$ & $19-23$ & [68] \\
\hline $\mathrm{MgCl}_{2}$ & LEUSBROCK et al. (2010) & $393-395$ & $19-23$ & [68] \\
\hline $\mathrm{Na}_{2} \mathrm{HPO}_{4}$ & LEUSBROCK et al. (2010) & $395-408$ & $21-23$ & [69] \\
\hline $\mathrm{NaH}_{2} \mathrm{PO}_{4}$ & LEUSBROCK et al. (2010) & $398-422$ & $20-24$ & [69] \\
\hline $\mathrm{K}_{2} \mathrm{HPO}_{4}$ & WOFFORD et al. (1995) & $400-450$ & $25-31$ & [70] \\
\hline $\mathrm{MgSO}_{4}$ & LEUSBROCK et al. (2010) & $385-401$ & $19-23$ & [69] \\
\hline $\mathrm{KOH}$ & WOFFORD et al. (1995) & $423-525$ & $22-30$ & {$[70]$} \\
\hline \multirow{2}{*}{$\mathrm{Na}_{2} \mathrm{CO}_{3}$} & \multirow{2}{*}{$\begin{array}{l}\text { KHAN \& ROGAK (2004) } \\
\text { LI et al. }(1999)\end{array}$} & \multirow{2}{*}{$\begin{array}{c}380-440 \\
450\end{array}$} & \multirow{2}{*}{$\begin{array}{l}24-25 \\
24-27\end{array}$} & [50] \\
\hline & & & & [71] \\
\hline $\mathrm{H}_{3} \mathrm{BO}_{3}$ & LI et al. (1999) & $425-450$ & 24 & [71] \\
\hline $\mathrm{CaCO}_{3}$ & MARTYNOVA et al. (1964) & 440 & 24 & [72] \\
\hline $\mathrm{NaOH}$ & URUSOVA M. A. (1974) & 400 & 28 & {$[73]$} \\
\hline $\mathrm{Mg}(\mathrm{OH})_{2}$ & MARTYNOVA et al. (1964) & 440 & 24 & {$[72]$} \\
\hline \multirow{4}{*}{$\mathrm{NaCl}$} & \multirow{4}{*}{$\begin{array}{c}\text { GALOBARDES et al. (1981) } \\
\text { ARMELLINI \& TESTER (1993) } \\
\text { IGASHI et al. }(2005) \\
\text { LEUSBROCK } \text { et al. }(2009)\end{array}$} & \multirow{4}{*}{$\begin{array}{c}400-550 \\
450-550 \\
350-400 \\
380-420\end{array}$} & \multirow{4}{*}{$\begin{array}{c}1-10 \\
10-25 \\
9-12 \\
17-24\end{array}$} & [58] \\
\hline & & & & [47] \\
\hline & & & & 66 \\
\hline & & & & [67] \\
\hline \multirow{7}{*}{$\mathrm{Na}_{2} \mathrm{SO}_{4}$} & \multirow{7}{*}{$\begin{array}{l}\text { RAVICH \& BOROVAYA (1964) } \\
\text { ARMELLINI \& TESTER (1993) } \\
\text { HODES }(1997) \\
\text { DiPIPPO et al. }(1999) \\
\text { ROGAK et al. }(1999) \\
\text { SHVEDOV et al. }(2000) \\
\text { KHAN \& ROGAK }(2004) \\
\end{array}$} & \multirow{7}{*}{$\begin{array}{l}320-370 \\
500 \\
342-363 \\
320-365 \\
370-505 \\
350-375 \\
382-397\end{array}$} & \multirow{7}{*}{$\begin{array}{l}20-25 \\
25 \\
25 \\
20-25 \\
25 \\
19-30 \\
24 \\
\end{array}$} & [74] \\
\hline & & & & [47] \\
\hline & & & & [75] \\
\hline & & & & [76] \\
\hline & & & & {$[77]$} \\
\hline & & & & [78] \\
\hline & & & & [50] \\
\hline
\end{tabular}

Table II: Presentation of all the solubility data available in the literature for inorganic salt in sub- and supercritical water.

ganic compound precipitates [79] or to develop an in situ turbidity measurement set up [49] in order to detect the nucleation point of precipitates and the different phases for inorganic salt mixtures.

As a summary, dealing with quantitative salt solubility measurements in sub- and supercritical conditions often lead in using two different methods. One consisting of the precipitation of a brine, while the other saturates pure water through a column filled with salt crystals. But even if these methods have been used several times by different research groups, solubility data remains quite scarce for a lot of inorganic salts. Moreover, these studies only concern binary mixture with water, without influence of any other species present in the solution. This leads us to the next topic, concerning salt mixtures.

\section{Part IV}

\section{Solubility with salt mixtures}

Despite the fact that some of the common salt's behavior under sub- and supercritical conditions are quite known, very few studies investigated the behavior of a mixture of two salts, and the effect that one can have on the solubility. One of the first studies on mixtures [76] managed to reconstruct a part of the ternary phase diagram of the $\mathrm{H}_{2} \mathrm{O}-\mathrm{NaCl}-\mathrm{Na}_{2} \mathrm{SO}_{4}$ mixture under supercritical conditions, up to $550^{\circ} \mathrm{C}$ and $25 \mathrm{MPa}$ (c.f. Figure 9). For the ternary figures, they used previous data [44, 47] to build the ternary phase diagram with a continuous topological method. These results correlate with VALYASHKO's prediction $[38,40]$ that the presence of a type I salt with a type II would increase the type II solubility with temperature.

Most of the experimental work regarding salt mix- 


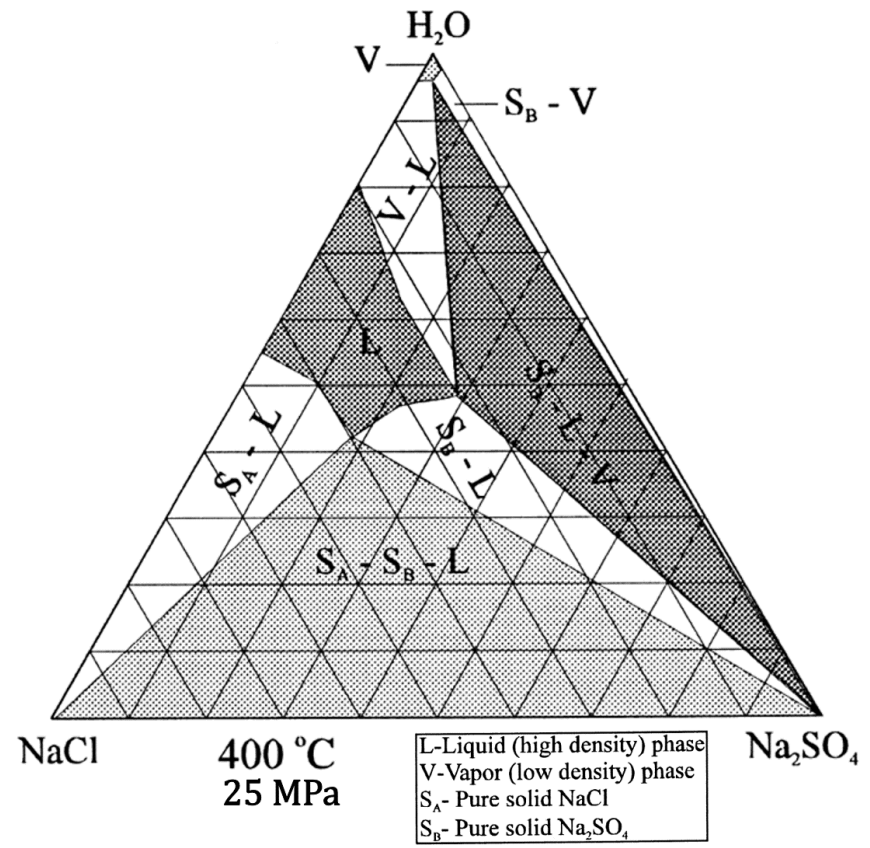

Figure 9: Example of the $\mathrm{H}_{2} \mathrm{O}-\mathrm{NaCl}-\mathrm{Na}_{2} \mathrm{SO}_{4}$ ternary diagram at $400^{\circ} \mathrm{C}, 25 \mathrm{MPa}$, from DiPIPPO et al.

tures has been done towards the improvement of the gasification processes [30-32, 80], with experimental set up built in order to analyse and separate brines and salt mixtures. In fact, for the last decade, a lot of research has been turned towards supercritical water gasification (SCWG) of biomass for hydrogen and/or methane production[1, 34, 81]. Key challenges for this kind of process are similar with SCWO, except that catalysts may be used. In this case, some inorganic ions can degrade or destroy the catalysts. It is then of great interest to be able to trap these poisonous ions. Using Modar like reactors, the aim of the set up is to improve the selective salt separation. In order to study this separation, various tests were performed with type I-type I, type I-type II and type II-type II mixtures [30-32]. First, looking at type I - type I possible interactions, no changes can be highlighted and the mixture seems to behave like the solution containing one type I salt. In contrast, type I - type II and type II - type II salt combinations show interesting results. For example, with the mixture $\mathrm{Na}_{3} \mathrm{PO}_{4} / \mathrm{K}_{2} \mathrm{SO}_{4}$ (type II - type II), as the salts precipitate, instead of recovering a $\mathrm{Na}_{3} \mathrm{PO}_{4} / \mathrm{K}_{2} \mathrm{SO}_{4}$ solution at the outlet, $\mathrm{Na}_{2} \mathrm{SO}_{4} / \mathrm{K}_{3} \mathrm{PO}_{4}$ (type II - type I) mixture is obtained, meaning that the formation of a type I salt in equilibrium with a type II salt is favored. Some exchanges between common ions of different salts can also be seen with $\mathrm{NaNO}_{3} / \mathrm{K}_{2} \mathrm{CO}_{3}$ (type I - type II) where at the end, $\mathrm{Na}_{2} \mathrm{CO}_{3}$ is mainly recovered. Regarding the mixtures of two types II salts (which cannot recombined into a type I salt), the behavior remains the same as a binary solution: precipitation and plugging occurs. As a conclusion of all the works about the behavior of salt mixtures, the authors declare that "it is not possible to predict the separation performance of a given salt mixture just by knowing the separation performance of the single salt solution" [32].

In the meantime, KRUSE et al. [80] published their results on another study on the improvement of supercritical gasification and the ways to catch poisonous salts for metal catalysts. Beginning with a liquid or solid brine inside a semi-continuous reactor (c.f. Figure 10), it is shown that some ions can be trapped inside, depending on the brine used. For example, a potassium brine $\left(\mathrm{KHCO}_{3}\right)$ is deposited inside before running the experiment. A brine solution containing sodium ions is then injected through the apparatus. The analysis performed on the exiting solution shows that the sodium concentration is lower than the initial concentration, and that potassium ions are mainly present at the outlet. Several other similar experiments have been done following the same procedure, with different kinds of brine or solid bed inside the reactor. These results tend to show the same conclusions as the previous papers [30-32] which is the ability of particular brines to trap some ions by playing on the solubility difference between two salts, and the mechanism by which certain salts are favored.

Earlier in the decade, a study was performed on the solubility of $\mathrm{Na}_{2} \mathrm{SO}_{4}$ and $\mathrm{Na}_{2} \mathrm{CO}_{3}$ under supercritical conditions [50], but also the individual solubility of both salts. According to this work, solubility remains the same above supercritical conditions, but is slightly reduced for $\mathrm{Na}_{2} \mathrm{SO}_{4}$ at near critical conditions, because of the presence of $\mathrm{Na}_{2} \mathrm{CO}_{3}$ in the solution. This influence on the solubility of one salt on the other would be due to the fact that they have a common ion. This leads to an excess in the concentration which would favor the precipitation of the less soluble salt (meaning $\mathrm{Na}_{2} \mathrm{SO}_{4}$ ), according to the common ion effect. Common ion effect is a direct implication of Le Chatelier's principle, which implies that a chemical equilibrium is favored in the direction of the products if the reactant concentrations are in excess. In the case of the salt mixture, the presence of $\mathrm{Na}^{+}$ions coming from $\mathrm{Na}_{2} \mathrm{CO}_{3}$ increases the sodium concentration for the precipitation of $\mathrm{Na}_{2} \mathrm{SO}_{4}$, leading to a small increase in the products side, thus a decrease in sodium sulfate solubility.

This effect from one salt on another, commonly called "salting in" effect if increasing the solubility and "salting out" when decreasing it, has been studied more recently [82]. Using a sealed inconel crucible and Differential Scanning Calorimetry (DSC), different ternary salt mixtures were studied by detecting the precipitation phenomenon, immiscibility limit and supercritical homogenization. This allows them to highlight salting in or salting out effects, looking at the changes in the precipitation temperatures. The study was focused on three type I salts $\left(\mathrm{K}_{2} \mathrm{CO}_{3}, \mathrm{Na}_{2} \mathrm{HPO}_{4}\right.$ and $\left.\mathrm{K}_{2} \mathrm{HPO}_{4}\right)$ and three type II $\left(\mathrm{Na}_{2} \mathrm{SO}_{4}, \mathrm{~K}_{2} \mathrm{SO}_{4}\right.$ and $\left.\mathrm{MgSO}_{4}\right)$ and small salting in effects are observed for $\mathrm{Na}_{2} \mathrm{SO}_{4} / \mathrm{K}_{2} \mathrm{SO}_{4}$ and $\mathrm{Na}_{2} \mathrm{SO}_{4} / \mathrm{Na}_{2} \mathrm{CO}_{3}$ mixtures. Regarding $\mathrm{MgSO}_{4}$ mixtures 


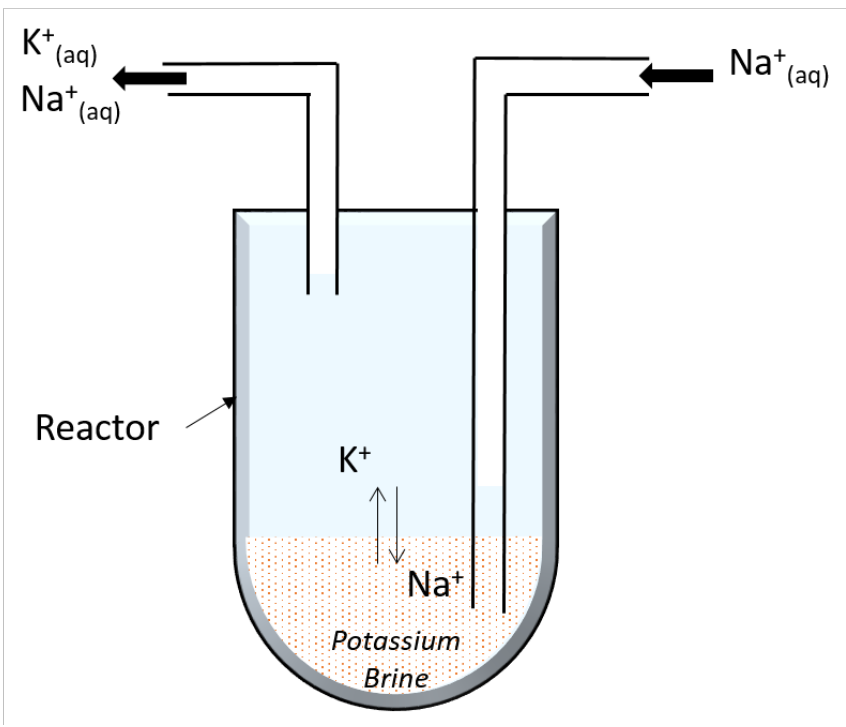

Figure 10: Scheme of the semi-continuous reactor used to trap poisonous ions, for gasification applications (adapted from [80]).

with either $\mathrm{Na}_{2} \mathrm{SO}_{4}$ or $\mathrm{K}_{2} \mathrm{SO}_{4}$, different effects occur depending on the molar ratio (salting in and salting out effects) between the salts. Surprisingly, a complicated behavior between $\mathrm{K}_{2} \mathrm{CO}_{3}$ and $\mathrm{Na}_{2} \mathrm{CO}_{3}$ does not allow the quantification of any salting effect, and no precipication is observed for phosphate salts (which could be in opposition with the solubility values for phosphate salts from the litterature [69], but the temperatures were actually not high enough to precipitate). Besides the fact that the work is not performed at constant pressure, it brings interesting information concerning salt mixtures.

The results enable to establish a trend in the ions solubility (comparing the precipitation temperature) in the following decreasing order : $\mathrm{K}^{+}>\mathrm{Na}^{+}>\mathrm{Mg}^{2+}$ for cations and $\mathrm{HPO}_{4}{ }^{2-}>\mathrm{SO}_{4}{ }^{2-}>\mathrm{CO}_{3}{ }^{2-}$ for anions. This solubility scale means that for example, $\mathrm{Na}_{2} \mathrm{CO}_{3}$ salt will be less soluble than $\mathrm{Na}_{2} \mathrm{SO}_{4}$ which will be less soluble than $\mathrm{K}_{2} \mathrm{SO}_{4}$. This solubility scale is in opposition with the trend from MARSHALL and VALYASHKO (Table I). The possible explanation given by the authors comes from the consideration of the ionic radius. A small ion with a single charge, like $\mathrm{Na}^{+}$, will lead to a small ionic radius, thus a strong electrostatic interaction with other ions leading to clustering and ion association prior to precipitation. Whereas a bigger ion like $\mathrm{K}^{+}$with a larger radius will have a weaker electrostatic interaction and will be less influenced by the drop in dielectric constant with temperature. Regarding $\mathrm{Mg}^{2+}$, the atom may be bigger, but as the ionic charge is also bigger, the resulting ionic radius is smaller than $\mathrm{K}^{+}$or $\mathrm{Na}^{+}$and it is very sensible with changes in dielectric constant. The exception of $\mathrm{CO}_{3}{ }^{2-}$ salts is quite interesting though. Based on its ionic radius, carbonate salts should be more soluble than sulfate ones. One hypothesis is that cation-anion interactions may be also influenced by the number of coordination sites, as sulfate ion own 6 sites compared to 3 for the carbonate ion, which could explain the changes in solubility.

Initial studies on salt mixture behaviors were quite consistent with the predictions of the salt type diagrams, as long as the interactions were not too complex. But more recent studies have begun to highlight much more intricated interactions between salts. Behaviors would then depend on the nature of the salts in presence (type I or II salt), their solubility limit, and the presence of a shared ion between them. Thanks to the new impetus brought by the research for supercritical gasification processes, several interaction mechanisms have been pointed out, and trends begin to appear. Even if there is no general behavior explanation yet, the ion radius theory regarding salt solubility scale is a good start for a better understanding of salt mixtures precipitation under suband supercritical conditions.

\section{Part V}

Predictive and semi-empirical models for inorganic salt solubility under supercritical conditions

Solubility data, regarding inorganic salts, is a key factor to understand precipitation, but as it has been shown earlier, experimental data is not always easy to produce. Especially under supercritical conditions, experimental set up becomes costly and unhandy. Some data concerning common salts like $\mathrm{NaCl}, \mathrm{KCl}$ or $\mathrm{Na}_{2} \mathrm{SO}_{4}$ can be found in the literature, but for more uncommon ones, data are most of the time missing. This is where predictive models could be very useful. Lots of theories have been developed on ion solvation or ion interaction with water for simple salts. Moreover, thermochemistry provides a very strong panel of key parameters to characterize an element or entity. Besides theoretical models, semi-empirical models most of the time fitted on experimental data, like Chrastil type equations, are also used due to their better accessibility. It often requires the use of basic thermodynamic parameters (such as thermal capacity, Gibbs enthalpy...) and are easy to handle and to apply to almost any type of data.

Depending on the product of interest, some correlation models will be more suited than other. Enthalpy and Cp approach, or Chrastil like models can be adapted for inorganic and organometallic compounds whereas FloryHuggins and cubic equation approach better fit the or- 
ganic and polymeric compounds, or fluid and molecule mixtures. The review from 2011 [83] sums up most of the papers between 2005 and 2010, dealing with solubility of solids in supercritical fluids, indicating which correlation model is used to fit the data and which temperature and pressure range is scanned. Way earlier, CHRASTIL [84] published in 1982 a paper about his famous semiempirical model on solubility in supercritical fluids. This model has then been adapted and modified for various compounds and systems. In 1986, PITZER et al. [85] publish a first paper on the modeling of the critical behavior of $\mathrm{NaCl}$ solutions. For the next seven years, he proposed several papers on the thermodynamic properties of electrolyte solutions under supercritical conditions [56, 86-94], developing the virial based Equation of States models for various salts like $\mathrm{NaCl}, \mathrm{KCl}$ or $\mathrm{NaOH}$.

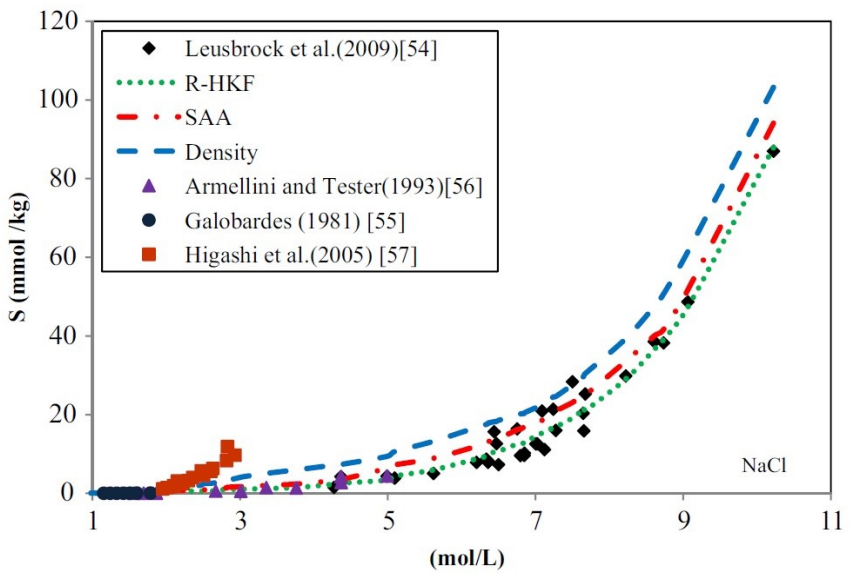

(a)

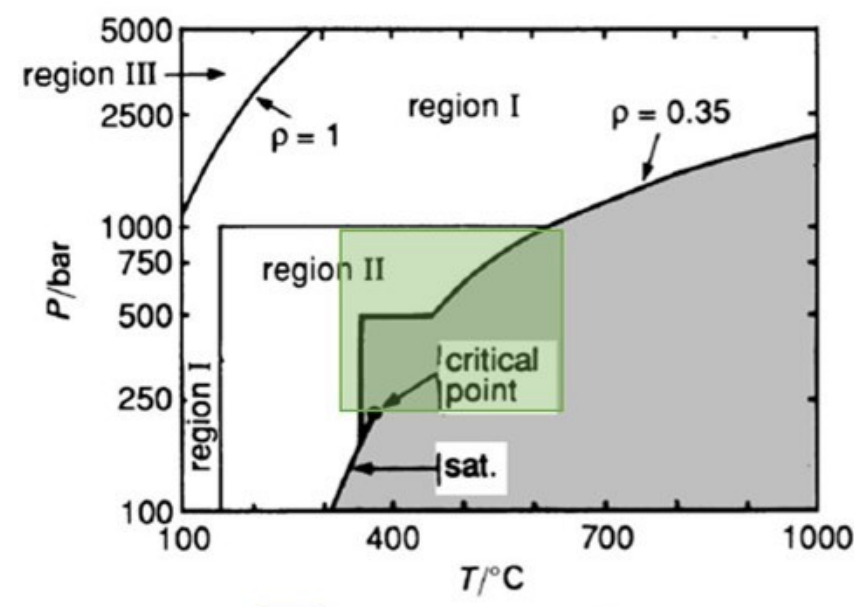

SAA extended domain

(b)

Figure 11: (a) Comparison of the different models with experimental data for $\mathrm{NaCl}$ from MASOODIYEH et al. [95] ; (b) Extension in the validity domain for the SAA model.
The limitation of Pitzer EoS on aqueous electrolyte solutions is that it requires a large number of characteristic parameters to be able to predict the solubility behavior for inorganic salts. Moreover, Pitzer equations are more convenient to be used for phase diagram determination rather than solubility curves. In order to dispose of a predictive model for solubility under high temperature and pressure, HELGESON et al. [96] (1981) published a significant paper for their new model, called HKF for Helgeson-Kirkham-Flowers. This model uses lots of different thermodynamic parameters, semi-empirical interaction functions, and some variables from the BORN theory for electrolyte interactions. Several other papers have been published later [97-100] to improve the model, which will then take the name of R-HKF model ( $\mathrm{R}$ stands for "Revisited"). Beyond its good abilities to predict solubility, the R-HKF model requires some specific thermodynamic parameters which can be difficult to determine (like the molar volume of the salt-solvent mixture according to the temperature and pressure), especially for uncommon salts. In order to try to dodge this problem, SUE et al. [101] (2002) created a simplified version of the R-HKF model, considering the temperature-density dependence of the semi-empirical part of the model, instead of the temperature-pressure dependence. This model is known as the SAA model (Sue-Adschiri-Arai) and is easier to handle. Recently, MASOODIYEH et al. [95] (2014) published a paper to summarize these different correlation models (R-HKF, SAA and Chrastil) and compare them with the literature data available to determine their precision (c.f. Figure $11(a)$ ). Without surprise, the R-HKF model provides the best fits with experimental data, but the SAA model is most of the time very close as well, with very few differences with R-HKF.

However, the R-HKF model requires at least 7 parameters for each compound involved in the considered chemical reaction. In the meantime of simplifying the R-HKF model into the SAA model, SUE et al. also extended the validity domain to the near- and supercritical region (c.f. Figure $11(b)$ ), using more recent experimental data of $\mathrm{NaCl}$ and $\mathrm{KCl}$ [102-105]. This improvement allows the SAA and R-HKF models to predict quite nicely the solubility of some common salts under supercritical conditions. Even though these predictive models well fit experimental data, their use remains quite complex, due to the number of parameter required, which are most of the time determined from experimental data. And as soon as experimental data are available, it will become more convenient to adopt a Chrastil like model, which is the most common method employed in the literature.

\section{Conclusion}

Research on SCWO processes for waste treatment has expended a lot during the last 20 years, and many technological gaps have been overpassed. Despite these im- 
provements, the precipitation of inorganic salt remains an important issue for most of the SCWO applications. Thanks to the broad development and accessibility of corrosion-resistant alloys and sapphire windows technologies, new investigations on the salt precipitation phenomena under supercritical conditions become possible. Since, lots of solubility data, phase diagrams and modelling have been established in sub- and supercritical conditions for the most common salt like $\mathrm{NaCl}$ or $\mathrm{Na}_{2} \mathrm{SO}_{4}$, but much less data exist for other salts. As a consequence, incoherencies appear between experimental results and predictive behaviors, such as the predicted increase in solubility of a given cation (anion) with the size of the anion (cation), which has been invalidated with the more recent salt mixture experiments. Moreover, the behavior of a single salt in water remains a very simplistic example compared to the complexity of a real waste treated in SCWO.

Regarding the solubility of salt mixtures, as cited before, it is for now not possible to predict the behavior of a given salt mixture just by knowing the behavior of the two separated salts. As the salt-water solubility data under supercritical conditions are still scarce in the literature, only very few papers are published regarding the study of the mixture, due to the complexity to analyse a solubility mixture without knowing the single solubility of each salt. Despite the great investment put into the classification of salt in order to highlight a trend for each type of salt, the behavior of ternary mixtures remains very difficult to predict and is most of the time specific to one application. Still, several types of predictive models have been developed for pure salt solubility in supercritical water conditions, and the experimental approach using DSC analysis is quite interesting and brings new hypothesis for salt classification depending on their solubility value and ionic radius. In addition, the influence of the oxidative compound or the degradation products like $\mathrm{CO}_{2}$, on the salt solubility is quite unknown although its presence in the SCWO process is non-negligible. This lack of data is quite surprising, as some studies show that the presence of dissolved salt in water influence the solubility of dissolved gas [106-117], it is very likely that dissolved oxidative compounds influence salt solubility as well.

For future research work, it is probably important to better understand the influence of the presence of other species on the solubility of inorganic salts (salting-in and salting-out effects) under near- and supercritical conditions with the aim of understanding the precipitation phenomena in SCWO processes. But it requires first some basic data for pure salts, as it is very probable that complex behaviors like diphasic domains (type I salts), miscibility limits or critical end-points will strongly influence the interactions with other salts or compounds.
[1] A. Loppinet-Serani, C. Aymonier, F. Cansell, Supercritical water for environmental technologies, Journal of Chemical Technology \& Biotechnology 85 (5) (2010) 583-589, 1.

[2] I. M. Smallwood, Handbook of organic solvent properties, Arnold, London, 1996, oCLC: 246959903.

[3] C. Aymonier, Traitement hydrothermal de déchets industriels spéciaux. Données pour le dimensionnement d'installations industrielles et concepts innovants de réacteurs sonochimique et électrochimique., Ph.D. thesis, Université de Bordeaux 1, 30 (Jul. 2000).

[4] M. D. Bermejo, M. J. Cocero, Supercritical water oxidation: A technical review, AIChE Journal 52 (11) (2006) 3933-3951.

[5] G. Brunner, Near critical and supercritical water. Part I. Hydrolytic and hydrothermal processes, The Journal of Supercritical Fluids 47 (3) (2009) 373-381, 22.

[6] P. Kritzer, N. Boukis, E. Dinjus, Corrosion of alloy 625 in aqueous solutions containing chloride and oxygen, Corrosion 54 (10) (1998) 824-834, 2.

[7] G. Brunner, Chapter 12 - Corrosion in Hydrothermal and Supercritical Water, in: G. Brunner (Ed.), Supercritical Fluid Science and Technology, Vol. 5 of Hydrothermal and Supercritical Water Processes, Elsevier, 2014, pp. 591-619, 3.

[8] P. Kritzer, Corrosion in high-temperature and supercritical water and aqueous solutions: a review, The Journal of Supercritical Fluids 29 (1-2) (2004) 1-29, 4.

[9] P. Kritzer, E. Dinjus, An assessment of supercritical water oxidation (SCWO): existing problems, possible solu- tions and new reactor concepts, Chemical Engineering Journal 83 (3) (2001) 207-214, 5.

[10] D. H. Xu, S. Z. Wang, Y. M. Gong, Y. Guo, X. Y. Tang, H. H. Ma, A novel concept reactor design for preventing salt deposition in supercritical water, Chemical Engineering Research and Design 88 (11) (2010) 1515$1522,10$.

[11] V. Vadillo, J. Sánchez-Oneto, J. R. Portela, E. J. Martínez de la Ossa, Problems in Supercritical Water Oxidation Process and Proposed Solutions, Ind. Eng. Chem. Res. 52 (23) (2013) 7617-7629, 29.

[12] D. Xu, C. Huang, S. Wang, G. Lin, Y. Guo, Salt deposition problems in supercritical water oxidation, Chemical Engineering Journal 279 (2015) 1010-1022, 28.

[13] M. Hodes, P. A. Marrone, G. T. Hong, K. A. Smith, J. W. Tester, Salt precipitation and scale control in supercritical water oxidation-Part A: fundamentals and research, The Journal of Supercritical Fluids 29 (3) (2004) 265-288, 6.

[14] P. A. Marrone, M. Hodes, K. A. Smith, J. W. Tester, Salt precipitation and scale control in supercritical water oxidation-part B: commercial/full-scale applications, The Journal of Supercritical Fluids 29 (3) (2004) 289-312, 7.

[15] W. Killilea, G. Hong, K. Swallow, T. Thomason, Supercritical water oxidation: Microgravity solids separation, SAE Technical Papers8.

[16] L. S. Cohen, D. Jensen, G. Lee, D. W. Ordway, Hydrothermal oxidation of Navy excess hazardous materials, Waste Management 18 (6) (1998) 539-546, 9. 
[17] G. T. Hong, W. R. Killilea, T. B. Thomason, United States Patent: 4822497 - Method for solids separation in a wet oxidation type process, 11 (Apr. 1989).

[18] C.-Y. Huang, United States Patent: 5100560 - Apparatus and method for supercritical water oxidation, 12 (Mar. 1992).

[19] H. Roche, M. Weber, C. Trepp, Design rules for the wallcooled hydrothermal burner (WHB), Chemical engineering \& technology 20 (3) (1997) 208-211, 13.

[20] J. Abeln, M. Kluth, G. Petrich, H. Schmieder, Supercritical water oxidation (SCWO): a process for the treatment of industrial waste effluents, High Pressure Research 20 (1-6) (2001) 537-547, 14.

[21] B. Wellig, K. Lieball, P. Rudolf von Rohr, Operating characteristics of a transpiring-wall SCWO reactor with a hydrothermal flame as internal heat source, The Journal of Supercritical Fluids 34 (1) (2005) 35-50, 15.

[22] K. Príkopský, B. Wellig, P. von Rohr, SCWO of salt containing artificial wastewater using a transpiring-wall reactor: Experimental results, The Journal of Supercritical Fluids 40 (2) (2007) 246-257, 16.

[23] M. Cocero, J. Martıńez, Cool wall reactor for supercritical water oxidation, The Journal of Supercritical Fluids 31 (1) (2004) 41-55, 17.

[24] A. F. Reid, A. H. Halff, United States Patent: 5425883 - Method for separation and removal of impurities from liquids, 18 (* June 20, 1995).

[25] J. W. Griffith, D. H. Raymond, The first commercial supercritical water oxidation sludge processing plant, Waste Management 22 (4) (2002) 453-459, 19.

[26] J. A. Titmas, United States Patent: 4594164 - Method and apparatus for conducting chemical reactions at supercritical conditions, 20 (Jun. 1986).

[27] C. Aymonier, M. Bottreau, B. Berdeu, F. Cansell, Ultrasound for Hydrothermal Treatments of Aqueous Wastes: Solution for Overcoming Salt Precipitation and Corrosion, Industrial \& Engineering Chemistry Research 39 (12) (2000) 4734-4740, 21.

[28] G. Brunner, Near and supercritical water. Part II: Oxidative processes, The Journal of Supercritical Fluids 47 (3) (2009) 382-390, 23.

[29] G. Brunner, Supercritical process technology related to energy and future directions - An introduction, The Journal of Supercritical Fluids 96 (2015) 11-20, 24.

[30] M. Schubert, J. W. Regler, F. Vogel, Continuous salt precipitation and separation from supercritical water. Part 1: Type 1 salts, The Journal of Supercritical Fluids 52 (1) (2010) 99-112, 25.

[31] M. Schubert, J. W. Regler, F. Vogel, Continuous salt precipitation and separation from supercritical water. Part 2. Type 2 salts and mixtures of two salts, The Journal of Supercritical Fluids 52 (1) (2010) 113-124, 26.

[32] M. Schubert, J. Aubert, J. B. Müller, F. Vogel, Continuous salt precipitation and separation from supercritical water. Part 3: Interesting effects in processing type 2 salt mixtures, The Journal of Supercritical Fluids 61 (2012) 44-54, 27.

[33] C. Morin, A. Loppinet-Serani, F. Cansell, C. Aymonier, Near- and supercritical solvolysis of carbon fibre reinforced polymers (CFRPs) for recycling carbon fibers as a valuable resource: State of the art, The Journal of Supercritical Fluids 66 (2012) 232-240.

[34] A. Loppinet-Serani, C. Reverte, F. Cansell, C. Ay- monier, Supercritical Water Biomass Gasification Process As a Successful Solution to Valorize Wine Distillery Wastewaters, ACS Sustainable Chemistry \& Engineering 1 (1) (2013) 110-117.

[35] A. Loppinet-Serani, C. Aymonier, Chapter 7 - Hydrolysis in Near- and Supercritical Water for Biomass Conversion and Material Recycling A2 - Anikeev, Vladimir, in: M. Fan (Ed.), Supercritical Fluid Technology for Energy and Environmental Applications, Elsevier, Boston, 2014, pp. 139-156.

[36] R. L. Scott, P. N. Van Konynenburg, Faraday Discuss. Chem. Soc. 49 (1970) 87-97, 31.

[37] L. Z. Boshkov, Dokl. Akad. Nauk SSSR 294 (1987) 901, 32.

[38] V. M. Valyashko, Fluid phase diagrams of ternary systems with one volatile component and immiscibility in two of the constituent binary mixturesPresented at the International Bunsen Discussion Meeting of the Deutsche Bunsen-Gesellschaft für Physikalische Chemie, Walberberg, Germany, 19-22 August, 2001., Physical Chemistry Chemical Physics 4 (7) (2002) 11781189, 33.

[39] V. Valyashko, Heterogeneous fluids in supercritical binary and ternary water-salt systems, Fluid Phase Equilibria 290 (1-2) (2010) 80-87, 34.

[40] V. M. Valyashko, Phase equilibria of water-salt sytems at high temperatures and pressures, in: A. H. Harvey (Ed.), Aqueous systems at elevated temperatures and pressures, elsevier academic press Edition, Physical Chemistry in water, steam and hydrothermal solutions, 35 .

[41] V. M. Valjaško (Ed.), Hydrothermal experimental data: [experimental data on aqueous phase equilibria and solution properties at elevated temperatures and pressures], Wiley, Chichester, 2008.

[42] W. L. Marshall, Water and its solutions at high temperature and high pressure, Chemistry 48 (2), 36.

[43] V. M. Valyashko, Phase equilibria in water-salt systems: some problems of solubility at elevated temperature and pressure, in: High temperature and high pressure electrochemistry in aqueous solutions, no. 4 in Natl. Assoc. Corrosion Eng., 1976, 37.

[44] F. J. Armellini, J. W. Tester, Experimental methods for studying salt nucleation and growth from supercritical water, The Journal of Supercritical Fluids 4 (1991) 254$264,38$.

[45] M. Benedict, Properties of Saturated Aqueous Solutions of Potassium Chloride at Temperatures above $250^{\circ} \mathrm{C}$., The Journal of Geology 47 (3) (1939) 252-276, 39.

[46] N. B. Keevil, Vapor Pressures of Aqueous Solutions at High Temperatures1, Journal of the American Chemical Society 64 (4) (1942) 841-850, 40.

[47] F. J. Armellini, J. W. Tester, Solubility of sodium chloride and sulfate in sub and supercritical water vapor from $450-550{ }^{\circ} \mathrm{C}$ and $100-250$ bar, Fluid Phase Equilibria 84 (1993) 123-142, 41.

[48] I. Leusbrock, S. J. Metz, G. Rexwinkel, G. F. Versteeg, Quantitative approaches for the description of solubilities of inorganic compounds in near-critical and supercritical water, The Journal of Supercritical Fluids 47 (2) (2008) 117-127, 42.

[49] P. Dell'Orco, H. Eaton, T. Reynolds, S. Buelow, The solubility of 1-1 nitrate electrolytes in supercritical water, The Journal of Supercritical Fluids 8 (1995) 217- 
$227,43$.

[50] M. Khan, S. Rogak, Solubility of Na2SO4, Na2CO3 and their mixture in supercritical water, The Journal of Supercritical Fluids 30 (3) (2004) 359-373, 44.

[51] A. Olander, H. Liander, The Phase diagram of sodium chloride and steam above the critical point, acta chemica scandinavica (4) (1950) 1437-1445, 45.

[52] S. Sourirajan, G. C. Kennedy, The system H 2 O$\mathrm{NaCl}$ at elevated temperatures and pressures, Am J Sci 260 (2) (1962) 115-141, 46.

[53] K. Khaibullin, N. Borisov, Experimental investigation of the thermal properties of aqueous and vapor solutions of sodium and potassium chlorides at phase equilibrium (1966) 518-52347.

[54] C. J. Parisod, E. Plattner, Vapor-liquid equilibria of the $\mathrm{NaCl}-\mathrm{H} 2 \mathrm{O}$ system in the temperature range $300-440{ }^{\circ} \mathrm{C}$, Journal of Chemical \& Engineering Data 26 (1981) 16$20,48$.

[55] J. L. Bischoff, R. Rosenbauer, The critical point and two-phase boundary of seawater $200-500^{\circ} \mathrm{C}$, Earth and Planetary Science Letters 68 (1984) 172-180, 49.

[56] J. Bischoff, R. Rosenbauer, K. S. Pitzer, The system $\mathrm{NaCl}-\mathrm{H} 2 \mathrm{O}$ : Relations of vapor-liquid nar the critical temperature of water and of vapor-liquid-halite from $300^{\circ} \mathrm{C}$ to $500^{\circ} \mathrm{C}$, Geochimica et Cosmochimica Acta 50 (1986) 1437-1444, 50.

[57] J. F. Galobardes, G. A. Owelmreen, L. B. Rogers, In Situ preconcentration for the determination of sodium ion in dry steam, Analytical Chemistry 53 (7) (1981) 1043-1047, 51.

[58] J. F. Galobardes, D. R. Van Hare, L. B. Rogers, Solubility of sodium chloride in dry steam, Journal of Chemical and Engineering Data 26 (4) (1981) 363-366, 52.

[59] M. A. Styrikovich, K. Khaibullin, D. G. Tschvirachvili, Solubility of salts in high pressure steam, Akad. Nauk. SSSR Dokl. 100 (1955) 1123-1126, 53.

[60] O. I. Martynova, Y. F. Samoilov, The formation of solutions of inorganic substances in water vapor, Russian Journal of Inorganic Chemistry 7 (4) (1962) 372-375, 54.

[61] O. I. Martynova, Y. F. Samoilov, Dissolution of sodium chloride in an atmosphere of water vapor of high parameters, Russian Journal of Inorganic Chemistry 2 (12) (1957) 236-243, 55.

[62] Y. V. Alekhin, A. G. Vakulenko, Thermodynamic parameters and solubility of $\mathrm{NaCl}$ in water vapor at 300$500^{\circ} \mathrm{C}$ up to 300 bar, Geochemistry International 25 (5) (1988) 97-110, 56.

[63] A. G. Vakulenko, Y. V. Alekhin, M. V. Rasina, Solubility and thermodynamic properties of alkali chlorides in steam, in: M. Pichal, O. Sifner (Eds.), Properties of water and steam, new york Edition, 1989, pp. 395-401, 57.

[64] J. M. H. G. W. Morey, The Solubility of Some Minerals in Superheated Steam at High Pressures, Economic Geology 46 (8) (1951) 821-835, 58.

[65] O. I. Martynova, Solubility of inorganic compounds in subcritical and supercritical water, in: D. deG. Jones, R. W. Staehle (Eds.), High temperature and high pressure electrochemistry in aqueous solutions, houston, tx Edition, 1976, 59.

[66] H. Higashi, Y. Iwai, K. Matsumoto, Y. Kitani, F. Okazaki, Y. Shimoyama, Y. Arai, Measurement and correlation for solubilities of alkali metal chlorides in wa- ter vapor at high temperature and pressure, Fluid phase equilibria 228 (2005) 547-551, 60.

[67] I. Leusbrock, S. J. Metz, G. Rexwinkel, G. F. Versteeg, Solubility of 1:1 Alkali Nitrates and Chlorides in NearCritical and Supercritical Water, Journal of Chemical \& Engineering Data 54 (12) (2009) 3215-3223, 61.

[68] I. Leusbrock, S. J. Metz, G. Rexwinkel, G. F. Versteeg, The solubility of magnesium chloride and calcium chloride in near-critical and supercritical water, The Journal of Supercritical Fluids 53 (1-3) (2010) 17-24.

[69] I. Leusbrock, S. J. Metz, G. Rexwinkel, G. F. Versteeg, The solubilities of phosphate and sulfate salts in supercritical water, The Journal of Supercritical Fluids 54 (1) (2010) 1-8, 66.

[70] W. T. Wofford, E. F. Gloyna, Solubility of potassium hydroxide and potassium phosphate in supercritical water, Journal of Chemical and Engineering Data 40 (4) (1995) 968-973.

[71] L. Li, E. F. Gloyna, SEPARATION OF IONIC SPECIES UNDER SUPERCRITICAL WATER CONDITIONS, Separation Science and Technology 34 (6-7) (1999) 1463-1477.

[72] O. I. Martynova, Some problems of the solubility of involatile inorganic compounds in water vapor at high temperatures and pressures, Russian Journal of Inorganic Chemistry 38 (1964) 587-592.

[73] M. A. Urusova, Phase equilibria in the sodium hydroxide-water and sodium chloride water systems at $350-550^{\circ} \mathrm{C}$, Russian Journal of Inorganic Chemistry 19 (3) (1974) 450-453.

[74] M. I. Ravich, F. E. Borovaya, Russian Journal of Inorganic Chemistry (9) (1964) 520-532.

[75] M. S. Hodes, K. S. Smith, W. A. J. Hurst, W. J. Bowers, P. Griffith, Vol. 12, 1997, pp. 107-119.

[76] M. M. DiPippo, K. Sako, J. W. Tester, Ternary phase equilibria for the sodium chloride-sodium sulfate-water system at 200 and 250 bar up to $400 \mathrm{C}$, Fluid Phase Equilibria 157 (2) (1999) 229-255, 63.

[77] S. N. Rogak, P. Teshima, Deposition of sodium sulfate in a heated flow of supercritical water, American Institute of Chemical Engineers. AIChE Journal 45 (2) (1999) 240.

[78] D. Shvedov, P. R. Tremaine, The solubility of sodium sulfate and the reduction of aqueous sulfate by magnetite under near-critical conditions, Journal of Solution Chemistry 29 (10) (2000) 889-904.

[79] W. S. Hurst, M. S. Hodes, W. J. Bowers Jr, V. E. Bean, J. E. Maslar, P. Griffith, K. A. Smith, Optical flow cell and apparatus for solubility, salt deposition and Raman spectroscopic studies in aqueous solutions near the water critical point, The Journal of Supercritical Fluids 22 (2002) 157-166, 62.

[80] A. Kruse, D. Forchheim, M. Gloede, F. Ottinger, J. Zimmermann, Brines in supercritical biomass gasification: 1. Salt extraction by salts and the influence on glucose conversion, The Journal of Supercritical Fluids 53 (1-3) (2010) 64-71, 64.

[81] A. Kruse, N. Dahmen, Water -A magic solvent for biomass conversion, The Journal of Supercritical Fluids 96 (2015) 36-45.

[82] J. Reimer, F. Vogel, Influence of anions and cations on the phase behavior of ternary salt solutions studied by high pressure differential scanning calorimetry, The Journal of Supercritical Fluids 109 (2016) 141-147, 65. 
[83] M. Škerget, Ž. Knez, M. Knez-Hrnčič, Solubility of Solids in Sub- and Supercritical Fluids: a Review, Journal of Chemical \& Engineering Data 56 (4) (2011) 694$719,67$.

[84] J. Chrastil, Solubility of solids and liquids in supercritical gases, The Journal of Physical Chemistry 86 (15) (1982) 3016-3021, 68.

[85] K. S. Pitzer, J. L. Bischoff, R. J. Rosenbauer, Critical behavior of dilute $\mathrm{NaCl}$ in $\mathrm{H} 2 \mathrm{O}$, Chemical Physics Letters 134 (1) (1986) 60-63, 69.

[86] R. T. Pabalan, K. S. Pitzer, Thermodynamics of concentrated electrolyte mixtures and the prediction of mineral solubilities to high temperatures for mixtures in the system Na-K-Mg-Cl-SO4-OH-H2O, Geochimica et Cosmochimica Acta 51 (1987) 2429-2443, 70.

[87] R. T. Pabalan, K. S. Pitzer, Thermodynamics of $\mathrm{NaOH}(\mathrm{aq})$ in hydrothermal solutions, Geochimica et Cosmochimica Acta 51 (1987) 829-837, 71.

[88] R. T. Pabalan, K. S. Pitzer, Heat capacity and other thermodynamic properties of Na2SO4(aq) in hydrothermal solutions and the solubilities of sodium sulfate minerals in the system Na-Cl-SO4-OH-H2O to $300^{\circ} \mathrm{C}$, Geochimica et Cosmochimica Acta 52 (1988) 23932404, 72 .

[89] K. S. Pitzer, Fluids both ionic and non-ionic, over wide ranges of temperature and composition, The Journal of Chemical Thermodynamics 21 (1989) 1-17, 73.

[90] K. S. Pitzer, J. C. Tanger, Reply - Critical exponents for the coexistence curves for $\mathrm{NaCl}-\mathrm{H} 2 \mathrm{O}$ near the critical temperature of $\mathrm{H} 2 \mathrm{O}$. Reply to comment by A. H. Harvey and J. M. H. Levelt Sengers, Chemical Physics Letters 156 (4) (1989) 418-419, 74.

[91] J. L. Bischoff, K. S. Pitzer, Liquid-vapor relations for the system NaCl-H2O : summary of the P-T-x surface from $300^{\circ} \mathrm{C}$ to $500^{\circ} \mathrm{C}$, American Journal of Science 289 (1989) 217-248, 75.

[92] J. C. Tanger, K. S. Pitzer, Thermodynamics of NaClH2O: A new equation of state for the near-critical region and comparison with other equations for adjoining regions, Geochimica et Cosmochimica Acta 53 (1989) 973-987, 76.

[93] A. Anderko, K. S. Pitzer, Equation of state representation of phase equilibria and volumetric properties of the system NaCl-H2O above $573 \mathrm{~K}$, Geochimica et Cosmochimica Acta 57 (1992) 1657-1680, 77.

[94] A. Anderko, K. S. Pitzer, Phase equilibria and volumetric properties of the systems $\mathrm{KCl}-\mathrm{H} 2 \mathrm{O}$ and $\mathrm{NaCl}-$ $\mathrm{KCl}-\mathrm{H} 2 \mathrm{O}$ above $573 \mathrm{~K}$ : Equation of state representation, Geochimica et Cosmochimica Acta 57 (1993) 4885$4897,78$.

[95] F. Masoodiyeh, M. Mozdianfard, J. Karimi-Sabet, Solubility estimation of inorganic salts in supercritical water, The Journal of Chemical Thermodynamics 78 (2014) 260-268, 80 .

[96] H. C. Helgeson, D. H. Kirkham, G. C. Flowers, Theoretical prediction of the thermodynamic behavior of aqueous electrolytes at high pressures and temperatures: IV. Calculation of activity coefficients, osmotic coefficients, and apparent molal and standard and relative partial molal properties to $600^{\circ} \mathrm{C}$ and $5 \mathrm{~kb}$, American Journal of Science 281 (1981) 1249-1516, 81.

[97] E. L. Shock, H. C. Helgeson, Calculation of the thermodynamic and transport properties of aqueous species at high pressures and temperatures: Correlation algo- rithms for ionic species and equation of state predictions to $5 \mathrm{~kb}$ and $1000^{\circ} \mathrm{C}$, Geochimica et Cosmochimica Acta 52 (1988) 2009-2036, 82.

[98] J. C. Tanger IV, H. C. Helgeson, Calculation of the thermodynamic and transport properties of aqueous species at high pressures and temperatures: revised equation of state for the standard partial molal properties of ions and electrolytes, American Journal of Science 288 (1988) 19-98, 83

[99] E. L. Shock, H. C. Helgeson, D. A. Sverjensky, calculation of the thermodynamic and transport properties of aqueous species at high pressures and temperatures: standard partial molal properties of inorganic neutral species, Geochimica et Cosmochimica Acta 53 (1989) 2157-2183, 84.

[100] E. L. Shock, E. H. Oelkers, J. W. Johnson, D. A. Sverjensky, H. C. Helgeson, Calculation of the thermodynamic properties of aqueous species at high pressures and temperatures. Effective electrostatic radii, dissociation constants and standard partial molal properties to $1000 \mathrm{C}$ and $5 \mathrm{kbar}$, J. Chem. Soc., Faraday Trans. 88 (6) (1992) 803-826, 85.

[101] K. Sue, T. Adschiri, K. Arai, Predictive model for equilibrium constants of aqueous inorganic species at subcritical and supercritical conditions, Industrial \& engineering chemistry research 41 (13) (2002) 3298-3306, 86.

[102] P. C. Ho, D. A. Palmer, R. E. Mesmer, Electrical conductivity measurements of aqueous sodium chloride solutions to $600 \mathrm{C}$ and $300 \mathrm{MPa}$, Journal of solution chemistry 23 (9) (1994) 997-1018, 87.

[103] P. C. Ho, D. A. Palmer, Ion association of dilute aqueous potassium chloride and potassium hydroxide solutions to $600^{\circ} \mathrm{C}$ and $300 \mathrm{MPa}$ determined by electrical conductance measurements, Geochimica et Cosmochimica Acta 61 (15) (1997) 3027-3040, 88.

[104] M. S. Gruszkiewicz, R. H. Wood, Conductance of dilute $\mathrm{LiCl}, \mathrm{NaCl}, \mathrm{NaBr}$, and $\mathrm{CsBr}$ solutions in supercritical water using a flow conductance cell, The Journal of Physical Chemistry B 101 (33) (1997) 6549-6559, 89.

[105] P. C. Ho, H. Bianchi, D. A. Palmer, R. H. Wood, Conductivity of dilute aqueous electrolyte solutions at high temperatures and pressures using a flow cell, Journal of solution chemistry 29 (3) (2000) 217-235, 90.

[106] S. Takenouchi, G. C. Kennedy, The solubility of carbon dioxide in nacl solutions at high temperatures and pressures, Am J Sci 263 (5) (1965) 445-454, 91.

[107] M. Gehrig, H. Lentz, E. U. Franck, The system water - carbon dioxide - sodium chloride to $773 \mathrm{~K}$ and 300 $\mathrm{MPa}$, Berichte der Bunsengesellschaft für physikalische Chemie 90 (6) (1986) 525-533, 92.

[108] J. A. Nighswander, N. Kalogerakis, A. K. Mehrotra, Solubilities of carbon dioxide in water and $1 \mathrm{wt} . \%$ sodium chloride solution at pressures up to $10 \mathrm{MPa}$ and temperatures from 80 to 200. degree. C, Journal of Chemical and Engineering Data 34 (3) (1989) 355-360, 93.

[109] F. J. Millero, F. Huang, A. L. Laferiere, Solubility of oxygen in the major sea salts as a function of concentration and temperature, Marine Chemistry 78 (4) (2002) 217-230, 94 .

[110] F. J. Millero, F. Huang, A. L. Laferiere, The solubility of oxygen in the major sea salts and their mixtures at 25 C, Geochimica et Cosmochimica Acta 66 (13) (2002) 2349-2359, 95. 
[111] F. J. Millero, F. Huang, Solubility of Oxygen in Aqueous Solutions of $\mathrm{KCl}, \mathrm{K}_{2} \mathrm{SO}_{4}$, and $\mathrm{CaCl}_{2}$ as a Function of Concentration and Temperature, Journal of Chemical \& Engineering Data 48 (4) (2003) 1050-1054, 96.

[112] F. J. Millero, F. Huang, T. B. Graham, Solubility of oxygen in some 1-1, 2-1, 1-2, and 2-2 electrolytes as a function of concentration at $25 \mathrm{C}$, Journal of solution chemistry 32 (6) (2003) 473-487, 97.

[113] Z. Duan, R. Sun, C. Zhu, I.-M. Chou, An improved model for the calculation of $\mathrm{CO} 2$ solubility in aqueous solutions containing $\mathrm{Na}+, \mathrm{K}+, \mathrm{Ca} 2+, \mathrm{Mg} 2+, \mathrm{Cl}-$, and SO42-, Marine Chemistry 98 (2-4) (2006) 131-139, 98.

[114] M. Geng, Z. Duan, Prediction of oxygen solubility in pure water and brines up to high temperatures and pressures, Geochimica et Cosmochimica Acta 74 (19) (2010) 5631-5640, 99.
[115] Y. Liu, M. Hou, G. Yang, B. Han, Solubility of CO2 in aqueous solutions of $\mathrm{NaCl}, \mathrm{KCl}, \mathrm{CaCl} 2$ and their mixed salts at different temperatures and pressures, The Journal of Supercritical Fluids 56 (2) (2011) 125-129, 100.

[116] N. Liu, C. Aymonier, C. Lecoutre, Y. Garrabos, S. Marre, Microfluidic approach for studying CO2 solubility in water and brine using confocal Raman spectroscopy, Chemical Physics Letters 551 (2012) 139-143, 101.

[117] P. J. Carvalho, L. M. Pereira, N. P. Gonçalves, A. J. Queimada, J. A. Coutinho, Carbon dioxide solubility in aqueous solutions of $\mathrm{NaCl}$ : Measurements and modeling with electrolyte equations of state, Fluid Phase Equilibria 388 (2015) 100-106, 102. 